\title{
Mineralogical and geochemical analysis of Fe-phases in drill-cores from the Triassic Stuttgart Formation at Ketzin $\mathrm{CO}_{2}$ storage site before $\mathrm{CO}_{2}$ arrival
}

\author{
Monika Kasina $^{1,2}$ - Susanne Bock ${ }^{3} \cdot$ Hilke Würdemann $^{1,4}$ • Dieter Pudlo ${ }^{3}$ • \\ Aude Picard ${ }^{5,6} \cdot$ Anna Lichtschlag $^{5,7} \cdot$ Christian März $^{8} \cdot$ Laura Wagenknecht $^{5}$.

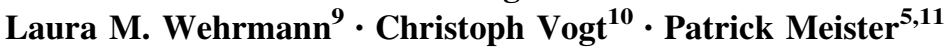

Received: 29 May 2016/Accepted: 3 February 2017/Published online: 16 February 2017

(c) The Author(s) 2017. This article is published with open access at Springerlink.com

\begin{abstract}
Reactive iron (Fe) oxides and sheet silicatebound $\mathrm{Fe}$ in reservoir rocks may affect the subsurface storage of $\mathrm{CO}_{2}$ through several processes by changing the capacity to buffer the acidification by $\mathrm{CO}_{2}$ and the permeability of the reservoir rock: (1) the reduction of threevalent $\mathrm{Fe}$ in anoxic environments can lead to an increase in $\mathrm{pH}$, (2) under sulphidic conditions, Fe may drive sulphur cycling and lead to the formation of pyrite, and (3) the leaching of $\mathrm{Fe}$ from sheet silicates may affect silicate diagenesis. In order to evaluate the importance of Fe-reduction on the $\mathrm{CO}_{2}$ reservoir, we analysed the Fe geochemistry in drill-cores from the Triassic Stuttgart Formation (Schilfsandstein) recovered from the monitoring well at the $\mathrm{CO}_{2}$ test injection site near Ketzin, Germany.
\end{abstract}

This article is part of a Topical Collection in Environmental Earth Sciences on "Subsurface Energy storage", guest-edited by Sebastian Bauer, Andreas Dahmke and Olaf Kolditz.

Patrick Meister

patrick.meister@univie.ac.at

1 Section 5.3 Geomicrobiology, GFZ German Research Centre for Geosciences, Helmholtz Centre Potsdam, Telegrafenberg, 14473 Potsdam, Germany

2 Institute of Geological Sciences, Jagiellonian University, Gronostajowa 3a, 30-387 Kraków, Poland

3 Institute of Geosciences, Friedrich Schiller University of Jena, Burgweg 11, 07737 Jena, Germany

4 Department of Engineering and Natural Sciences, University of Applied Science Merseburg, 06217 Merseburg, Germany

5 Max-Planck Institute for Marine Microbiology, Celsiusstrasse 1, 28359 Bremen, Germany

6 Department of Organismic and Evolutionary Biology, Harvard University, 16 Divinity Avenue, Cambridge, MA 02138, USA
The reservoir rock is a porous, poorly to moderately cohesive fluvial sandstone containing up to 2-4 wt $\%$ reactive Fe. Based on a sequential extraction, most Fe falls into the dithionite-extractable Fe-fraction and $\mathrm{Fe}$ bound to sheet silicates, whereby some $\mathrm{Fe}$ in the dithionite-extractable Fe-fraction may have been leached from illite and smectite. Illite and smectite were detected in core samples by X-ray diffraction and confirmed as the main Fe-containing mineral phases by X-ray absorption spectroscopy. Chlorite is also present, but likely does not contribute much to the high amount of $\mathrm{Fe}$ in the silicate-bound fraction. The organic carbon content of the reservoir rock is extremely low $(<0.3 \mathrm{wt} \%)$, thus likely limiting microbial Fe-reduction or sulphate reduction despite relatively high concentrations of reactive Fe-mineral phases in the reservoir rock and sulphate in the reservoir fluid. Both processes could, however, be fuelled by organic matter that is mobilized by

National Oceanography Centre, University of Southampton Waterfront Campus, European Way, Southampton SO14 3ZH, UK

8 School of Civil Engineering and Geoscience, Drummond Building, Newcastle University, Newcastle-upon-Tyne NE1 7RU, UK

9 School of Marine and Atmospheric Sciences, Stony Brook University, Stony Brook, NY 11794-5000, USA

10 Center for Crystallography and Applied Material Sciences, Department of Geosciences, University of Bremen, Bibliothekstraße 1, 28359 Bremen, Germany

11 Department of Geodynamics and Sedimentology, University of Vienna, Althanstr. 14, 1090 Vienna, Austria 
the flow of supercritical $\mathrm{CO}_{2}$ or introduced with the drilling fluid. Over long time periods, a potential way of liberating additional reactive $\mathrm{Fe}$ could occur through weathering of silicates due to acidification by $\mathrm{CO}_{2}$.

Keywords Ketzin $\cdot$ Stuttgart formation $\cdot \mathrm{CO}_{2}$ capture and storage (CCS) · Fe-mineralogy $\cdot$ Supercritical $\mathrm{CO}_{2}$. Microbial activity

\section{Introduction}

As a mitigation strategy to reduce the emission of the greenhouse gas carbon dioxide $\left(\mathrm{CO}_{2}\right)$ produced during the combustion of fossil fuel, storage of $\mathrm{CO}_{2}$ below the earth surface is considered as a potentially important technology (IPCC 2005; IEA 2013). While the feasibility and longterm effectiveness of this approach are still debated, several large-scale experiments have been conducted, and demonstration projects are active to better understand the behaviour of the rock reservoir during injection and longterm storage of $\mathrm{CO}_{2}$ (IPCC 2005). Besides the physical properties, the geochemical changes in rocks and pore waters of the storage formation and the microbiology in the rock aquifer also need to be better understood. A largescale test injection of $\mathrm{CO}_{2}$ has been conducted near the town of Ketzin, Germany, between 2008 and 2013 (e.g. Würdemann et al. 2010; Martens et al. 2012, 2013). The reservoir rock is a porous sandstone belonging to the Stuttgart Formation (Fm.; former Schilfsandstein) and occurs at a depth of approximately $630-650 \mathrm{~m}$. The reservoir is exemplary for other storage sites, where typically porous siliciclastic rocks overlain by an impermeable cap rock are used for gas storage, such as at the Sleipner gas storage site in the North Sea, where the $\mathrm{CO}_{2}$ is injected into sands of the Miocene-Pliocene Utsira Fm. (e.g. Lackner 2003; Zweigel et al. 2004) and others (IPCC 2005) or considered for storage, such as the Early Jurassic Navajo Sandstone (Colorado Plateau, western USA; Chan et al. 2000, 2005; Parry et al. 2007).

In siliciclastic sediments and rocks, $\mathrm{Fe}$ is commonly the most abundant redox-active solid-phase element and plays an important role in biogeochemical cycling due to its function as electron donor or acceptor for microbial processes in the deep biosphere (e.g. Froelich et al. 1979; Lovley and Phillips 1986; Canfield et al. 1993). In the subsurface, abiotic reactions and microbial Fe-metabolism may lead to the dissolution or formation of various $\mathrm{Fe}$ phases, such as Fe-oxides, hydroxides, sulphides or carbonates. In $\mathrm{CO}_{2}$ storage reservoirs, reactions involving $\mathrm{Fe}$ may affect the geochemistry in several ways: (1) the reduction of $\mathrm{Fe}(\mathrm{III})$, both abiotic and microbially mediated, leads to an increase in the $\mathrm{pH}$, buffering the acidification imposed by the dissociation of injected $\mathrm{CO}_{2}$ (Coleman and Raiswell 1995; Curtis et al. 1986; Fisher et al. 1998). This process would then further support the sequestration of $\mathrm{CO}_{2}$ in the form of dissolved bicarbonate or even induce the precipitation of solid-phase carbonate, hence permanently trapping the $\mathrm{CO}_{2}$. While carbonate precipitation is generally favourable for $\mathrm{CO}_{2}$ trapping, it causes problems in proximity to the injection well as it may reduce porosity and thereby injectivity of $\mathrm{CO}_{2}$. (2) In combination with dissimilatory sulphate reduction, $\mathrm{Fe}$ reduction may drive sulphur cycling via the formation of insoluble Fe-sulphide precipitates. Also, Fe-sulphides may form as a result of corrosion of the drill string or injection pipelines by oxidation of elemental $\mathrm{Fe}$ to $\mathrm{Fe}(\mathrm{II})$ coupled to sulphate reduction (Enning et al. 2012). Such dissolution-precipitation reactions would alter the porosity and permeability of the reservoir rock. (3) The microbially induced changes of valence states in silicate-bound $\mathrm{Fe}$ may have an impact on silicate weathering (Santelli et al. 2001), which could alter the $\mathrm{pH}$ and alkalinity over a long period of time.

In order to predict the geochemical changes associated with the oxidation and reduction of $\mathrm{Fe}$ after injection of $\mathrm{CO}_{2}$ into the reservoir rocks, this study provides a semiquantitative assessment of the Fe-mineral phases occurring in the reservoir rock at the Ketzin injection site, in the monitoring well, before the arrival of $\mathrm{CO}_{2}$. Total Fe-content was analysed by X-ray fluorescence, and differently reactive $\mathrm{Fe}$-mineral fractions were quantified by $\mathrm{X}$-ray diffraction, as well as by using a sequential extraction procedure (Poulton and Canfield 2005). Reduced sulphidebound Fe-phases were extracted as acid-volatile sulphide and chromium-reducible Fe-sulphur fractions (AVS and CRS, respectively) and compared with the total organic carbon content available as a substrate for microbial $\mathrm{Fe}$ and $\mathrm{SO}_{4}{ }^{2-}$ reduction. Furthermore, the predominant structure of solid Fe-phases was analysed by synchrotron-based $\mathrm{X}$-ray spectroscopy. Results provide better constraints on the microbial and abiotic Fe-oxidation/reduction and their potential effect on subsurface $\mathrm{CO}_{2}$ storage reservoirs in the Stuttgart Fm. and other porous sandstones that could be suitable for $\mathrm{CO}_{2}$ injection.

\section{Geological setting}

The Ketzin $\mathrm{CO}_{2}$ storage site is located $25 \mathrm{~km}$ west of Berlin (Germany; Würdemann et al. 2010). The reservoir horizon is up to $20 \mathrm{~m}$ thick and occurs at approximately 630-650 m depth on the southern limb of an east-west striking anticline (Fig. 1a; Norden et al. 2010). The reservoir rock is a poorly to moderately cohesive reddish sandstone deposited in a fluvial environment during a 


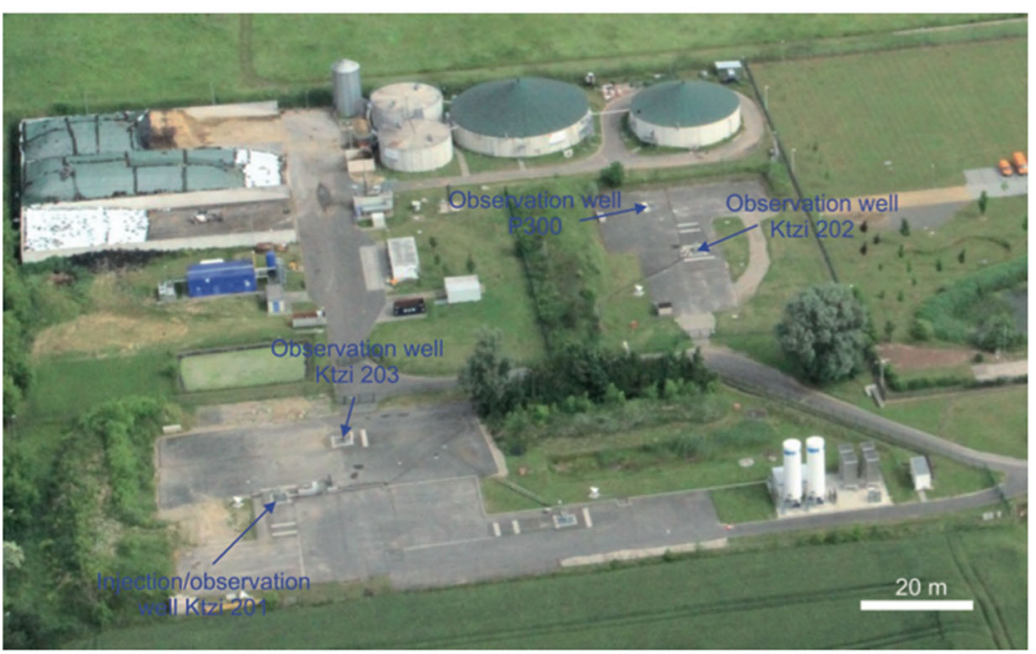

A

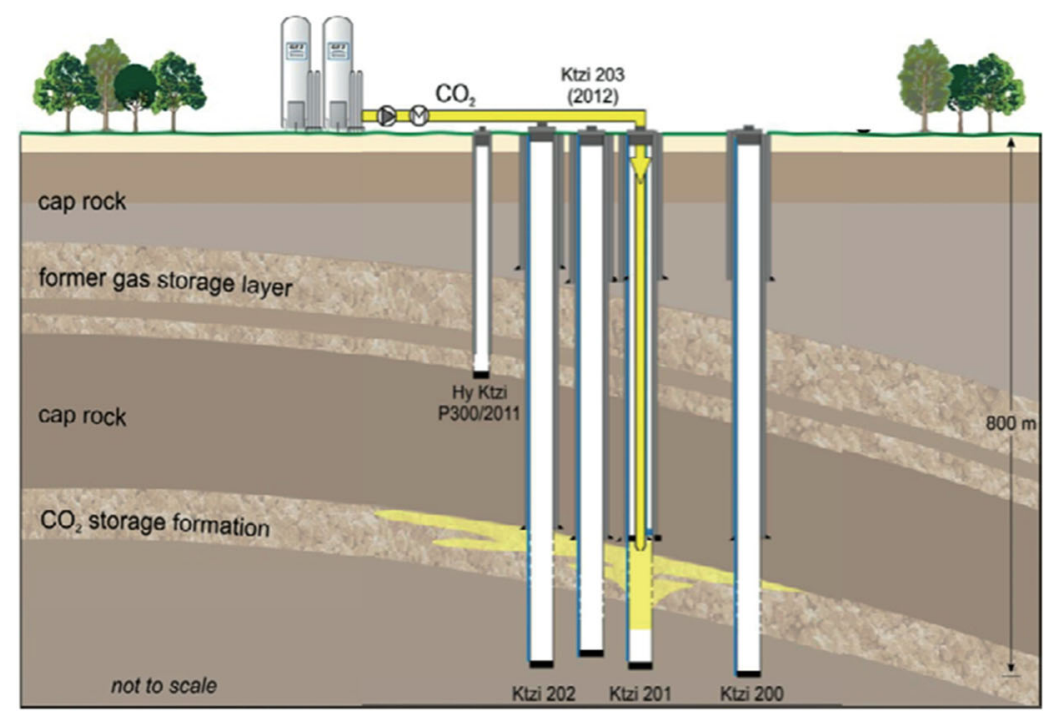

B

Fig. 1 a Aerial view with scientific infrastructure at the Ketzin $\mathrm{CO}_{2}$ injection site in June 2013 (changed after Martens et al. 2014). b Schematic cross section through the Ketzin $\mathrm{CO}_{2}$ storage site showing the injection well and the two monitoring wells (courtesy to

humid period in the otherwise arid Germanic Basin during the Late Triassic (the Carnian Pluvial Episode; Kozur and Bachmann 2010, and references therein). Under the arid conditions, large amounts of evaporite were deposited, which are preserved in underlying units and partially within the Stuttgart Fm. as gypsum and anhydrite cements which precipitated from supersaturated hypersaline and sulphate-rich brine during early diagenetic processes. Arid conditions as well as diagenetic mobilization and re-oxidation led to the coating of grains with Fe-oxide/hydroxides (Förster et al. 2010). Previous studies reported an overall high $\mathrm{Fe}$-content in the sandstones $\left(6-7 \mathrm{wt} \% \mathrm{Fe}_{2} \mathrm{O}_{3}\right.$

\section{Ktzi 202/2007}

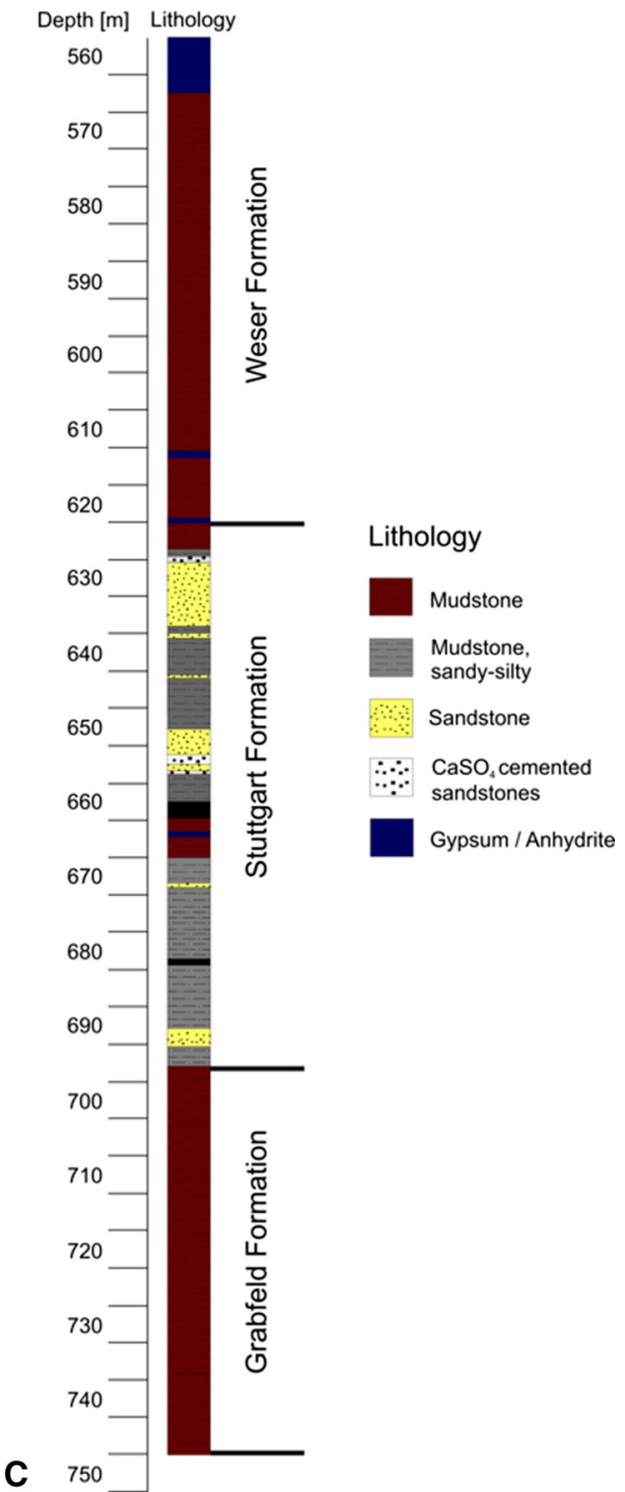

Pilotstandort Ketzin, coordinated by Deutschen GeoForschungsZentrums GFZ; www.co2ketzin.de). c Lithostratigraphic column through the Triassic to Tertiary units, modified after (Norden and Frykman 2013)

tot) of the Stuttgart Fm., partly derived from volcanic rock fragments (Förster et al. 2010).

The porous sandstone of the Stuttgart Fm. (Fig. 1b) overlies impermeable mudstone of the Grabfeld Fm. (Förster et al. 2006; Norden and Frykman 2013) and is sealed off by $200 \mathrm{~m}$ of mudstone of the Upper Triassic Weser Fm., Arnstadt Fm. and Exter Fm. A shallower reservoir is present at $250-400 \mathrm{~m}$, which during previous years was used for natural gas storage (Förster et al. 2006; Würdemann et al. 2010). This shallower reservoir is sealed by argillaceous sediments of Tertiary age. One injection well for $\mathrm{CO}_{2}$-injection (Ktzi 201) and two observation 
wells (Ktzi 200 and Ktzi 202) for monitoring the movement of the $\mathrm{CO}_{2}$ in the formation were drilled in 2007. A third observation well (Ktzi 203) was drilled in 2012. The injection and observation wells were drilled to depths of 750-800 m (Prevedel et al. 2008; Schilling et al. 2009; Förster et al. 2010; Würdemann et al. 2010). In 2011, an additional (fourth) shallow well (P300) was drilled ca. $25 \mathrm{~m}$ north-west from the observation well Ktzi 202, to monitor hydraulic and geochemical impacts of $\mathrm{CO}_{2}$ on the groundwater of the shallower aquifer overlying the reservoir rock of Stuttgart Fm. and the caprock. It reached about $450 \mathrm{~m}$ deep, into the Upper Triassic (Fig. 1c; Pellizzari et al. 2017; Martens et al. 2014). The reservoir rock has a porosity of $13-26 \%$ and a permeability of $40-110 \mathrm{mD}$ (Wiese et al. 2010). A temperature of $35^{\circ} \mathrm{C}$ was measured at the injection depths at $650 \mathrm{~m}$. The chemical composition of the reservoir fluid is dominated by the presence of sodium (ca. $90 \mathrm{~g} / \mathrm{l}$ ), calcium (2 g/l) and chloride (ca. $135 \mathrm{~g} /$ 1). The sulphate $\left(\mathrm{SO}_{4}{ }^{2-}\right)$ concentration was about $4 \mathrm{~g} / \mathrm{l}$ and the Fe-concentration $\left(\mathrm{Fe}_{\text {tot }}\right) 5.5-7.4 \mathrm{mg} / \mathrm{l}$. The total dissolved solid content (TDS) was $235 \mathrm{~g} / 1$ and the $\mathrm{pH}$ was 6.5. For more details concerning the chemical characteristics of the reservoir fluids, see Würdemann et al. (2010).

The $\mathrm{CO}_{2}$ injection started on 30 June 2008 and ended on 29 August 2013 with 67,271 t of supercritical $\mathrm{CO}_{2}$ injected into the reservoir. The gas consisted of $\mathrm{CO}_{2}(99.7-99.9 \%$ purity) with traces of $\mathrm{N}_{2}, \mathrm{He}$ and $\mathrm{CH}_{4}$ (Martens et al. 2012). According to Würdemann et al. (2010), the migration of $\mathrm{CO}_{2}$ was confirmed when the arrival of $\mathrm{CO}_{2}$ at the first observation well (Ktzi 200) was detected after three weeks of injection of about $500 \mathrm{t}$ of gas, and at the second observation well (Ktzi 202) nine months after the beginning of injection when ca. 11,000 t was injected. More details concerning the site operations can be found in Würdemann et al. (2010) and citations therein. Ivandic et al. (2015) monitored the $\mathrm{CO}_{2}$ plume evolution.

\section{Methods}

\section{Sample preparation}

During coring of the injection (Ktzi 201) and two monitoring wells (Ktzi 200 and 202), a water-based $\mathrm{CaCO}_{3}$ / bentonite/organic polymer drill mud, containing carboxymethylcellulose (CMC; Wandrey et al. 2010), was used to lubricate the drill bit, transport cuttings to the surface and stabilize and maintain the bottom-hole pressure (Grace 2007). CMC was used because it is a biodegradable organic polymer and does not pollute the subsurface environment. For the third deep observation well (Ktzi 203), a bentonite drill mud containing cellulose-based polymers [CMC and polyanionic cellulose (PAC)] and a natural polysaccharide-based polymer (Biolam) was used together with $\mathrm{K}_{2} \mathrm{CO}_{3}$ (Pellizzari et al. 2013). For well P300 (shallow hydraulic and geochemical monitoring well) reaching the aquifer above the $\mathrm{CO}_{2}$ storage formation (Exter Fm.), a $\mathrm{K}_{2} \mathrm{CO}_{3}$-based drill mud was used (Pellizzari et al. 2013).

For this study, aliquots from six core sections from the observation well Ktzi 202, sampled between 627 and $638 \mathrm{~m}$ depth before the arrival of the $\mathrm{CO}_{2}$, were investigated for their Fe-mineralogy (Table 1). After coring, the reservoir rock material was roughly cleaned using sterile synthetic formation fluid to remove the drill mud. Subsequently, rock core samples were wrapped into autoclaved aluminium foil and stored at $4{ }^{\circ} \mathrm{C}$ until processing. Seven samples were immediately processed, whereby the outer $2 \mathrm{~cm}$ of rock material was removed using an autoclaved chisel to prevent penetration of drill mud into the rock core (Wandrey et al. 2010). Subsequently, the samples were shock-frozen in liquid nitrogen and stored at $-20{ }^{\circ} \mathrm{C}$.

For SEM analyses, sub-samples were freeze-dried and ground to $<10 \mu \mathrm{m}$. To specifically target the Fe-composition of the sand grain coatings, some of the poorly cohesive sandstone samples were slightly crushed to disintegrate the single sand grains, but not milled to a powder. Thin sections of two selected samples were analysed under a petrographic microscope.

The reservoir fluid retrieved during the hydraulic tests and downhole sampling was analysed, and physico-chemical parameters were determined. For more details, see Würdemann et al. (2010). The hydraulic pumping tests were carried out as open-hole tests with production rates held at the maximal achievable rate. The fluids were collected directly from the well head, filled into sterilized glass bottles, cooled and transferred to the laboratory for chemical and molecular biological analyses.

\section{Scanning electron microscopy with energy- dispersive spectrometry (SEM-EDS)}

Air-dried and disintegrated sandstone fragments were mounted on SEM stubs using conducting tape, coated with carbon and examined with an Ultra 55 Plus (Carl Zeiss SMT) scanning electron microscopy (SEM) operating at an accelerating voltage of $20 \mathrm{kV}$, using the secondary electron (SE) signal. Energy-dispersive X-ray (EDX) spectroscopy was used for quantitative elemental analyses. Identification of elements in spot analyses and their distribution using the option of automatic or manual search of elements were performed using the analytical software Noran Vantage NSS. Element abundances were determined from the EDX spectra by integrating peak areas and normalizing the results to $100 \%$. 
Table 1 (A) Integrated major peak areas of all minerals detected in bulk XRD analyses of Stuttgart Fm Sandstone from well Ktzi 202. (B) Illite crystallinity as FWHM is based on the left and right edges of the peak

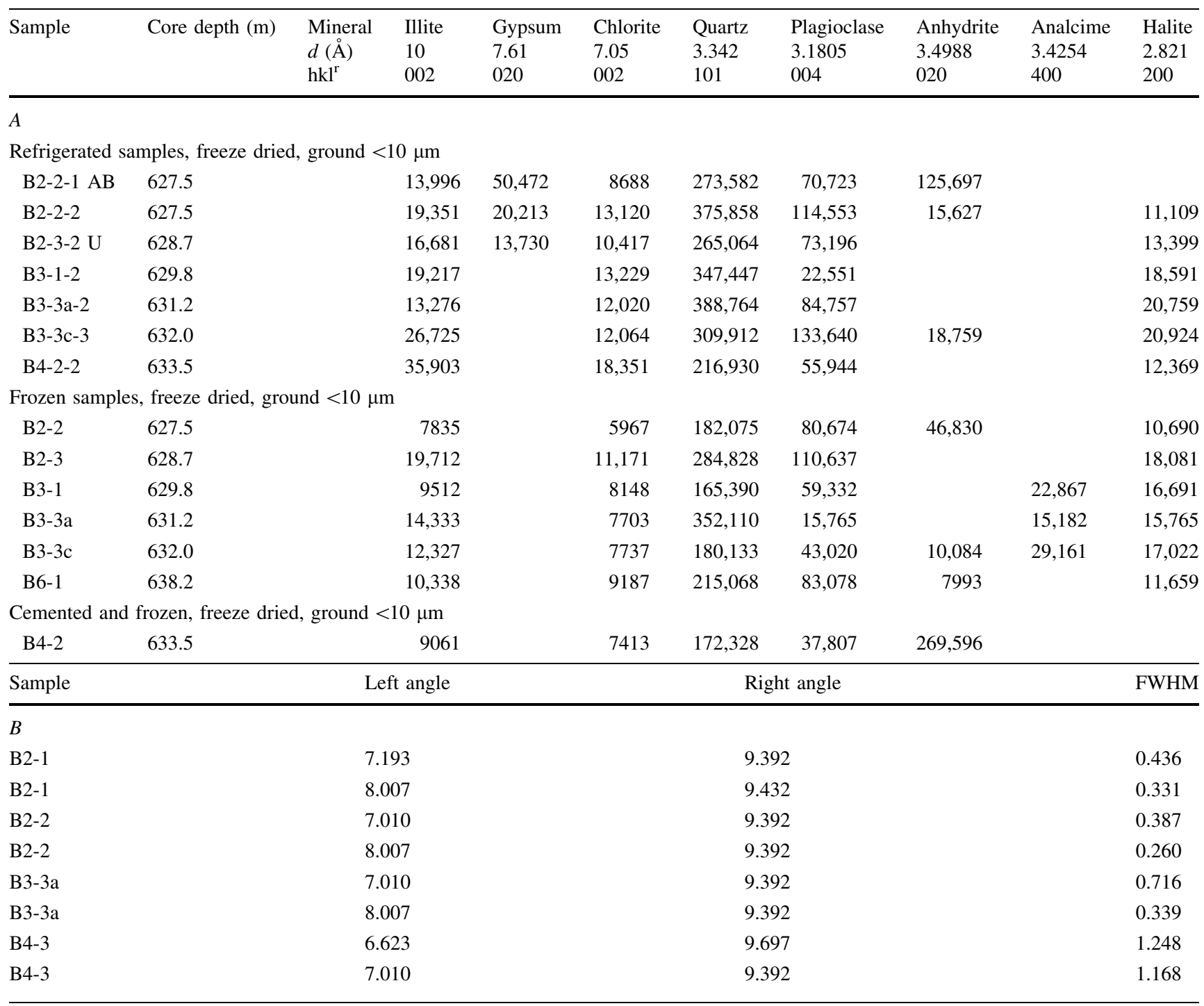

Muscovite $<0.25^{\circ} 2 \theta$

Illite $0.25^{\circ}-0.4^{\circ} 2 \theta$

Poorly crystalline illite $>0.4^{\circ} 2 \theta$ (Meunier and Velde 2004)

\section{X-ray diffraction}

The mineralogical content of sediment was analysed by a Philips XPERT pro X-ray diffractometer at the University of Bremen. $\mathrm{CuK} \alpha$ radiation was used and the samples were scanned from $3^{\circ}$ to $85^{\circ}(2 \theta)$. Relative abundances of different minerals were estimated from integrated peak areas.

In addition, the clay fraction of four selected samples with the highest clay mineral content was separated according to the procedure of Moore and Reynolds (1997). For these analyses, sandstone samples were disaggregated using a hydraulic press. Siltstones were placed in a plastic bag, gently squeezed by hand and dispersed with distilled water in an Atterberg cylinder. The 75-100 mg of tetrasodium pyrophosphate $\left(\mathrm{Na}_{4} \mathrm{P}_{2} \mathrm{O}_{7} \times 10 \mathrm{H}_{2} \mathrm{O}\right)$ was added to $500 \mathrm{ml}$ of suspension to prevent coagulation. The fraction $<2 \mu \mathrm{m}$ was prepared as a suspension. A $1-1.5 \mathrm{ml}$ of suspension was pipetted onto a porous ceramic tile made of corundum. The water was drained through the tile by means of a suction pump, which allowed the clay particles to settle with an orientation parallel to the surface. X-ray diffraction patterns of the separated clay fraction were acquired by a Bruker D8 (LynxEye) diffractometer. CuK $\alpha$ radiation was used and the samples were scanned from $3^{\circ}$ to $70^{\circ}(2 \theta)$. 
Each sample was prepared as oriented air-dried sample, as glycolized under ethylene glycol atmosphere for $12 \mathrm{~h}$ at $50{ }^{\circ} \mathrm{C}$ and as tempered at $550{ }^{\circ} \mathrm{C}$ for $1 \mathrm{~h}$. Clay minerals were identified with the Powder Diffraction File $\left(\mathrm{PDF}^{\circledR}\right)$ Database and the Crystallography Open Database (COD; Grazulis et al. 2009).

\section{Total, organic and inorganic carbon}

Total carbon (TC) and total sulphur (TS) contents were determined with a Carlo Erba NA-1500 CNS analyzer using in-house standard (DAN1). Total inorganic carbon (TIC) content was measured using a CM $5012 \quad \mathrm{CO}_{2}$ Coulometer (UIC) after acidification with phosphoric acid (3 M). Precisions $(2 \sigma)$ were $0.08 \mathrm{wt} \%$ for TC, $0.05 \mathrm{wt} \%$ for TIC and $0.04 \mathrm{wt} \%$ for TS. Total organic carbon (TOC) was calculated as the difference between TC and TIC.

\section{X-ray fluorescence}

For the elemental analysis, approximately $4 \mathrm{~g}$ of sediment was dried, finely ground, poured into sample cups and firmly pressed to remove air from the interstices. Samples were analysed using the compact benchtop energy-dispersive polarization X-ray fluorescence (EDPXRF) analysis system Spectro Xepos. Standard deviation of repeated measurements was $\leq 1 \%$, and the detection limit corresponds to a signal three times the standard deviation (Wien et al. 2005).

\section{Sequential extraction of iron}

A sequential Fe-extraction was performed using the method of Poulton and Canfield (2005). The following five solutions were used for extraction: (1) $1 \mathrm{M} \mathrm{Na}$-acetate $(\mathrm{pH}$ adjusted to 4.5 with acetic acid) $(24 / 48 \mathrm{~h})$; (2) $1 \mathrm{M}$ hydroxylamine- $\mathrm{HCl}$ in $25 \%$ (v/v) acetic acid (48 h); (3) $50 \mathrm{~g} / \mathrm{l} \mathrm{Na}$-dithionite in $0.35 \mathrm{M}(21 \mathrm{ml} / \mathrm{l})$ acetic acid/0.2 M $(58.8 \mathrm{~g} / \mathrm{l}) \mathrm{Na}$-citrate (dithionite solution always prepared fresh), pH 4.8 (2 h); (4) $0.2 \mathrm{M}$ (28.4 g/l) ammonium oxalate/0.17 M (21.4 g/l) oxalic acid, $\mathrm{pH} 3.2$ (6 h); and (5) boiling concentrated $\mathrm{HCl}$ (1 min). The efficiency and specificity of the method were tested by Poulton and Canfield (2005) for different minerals: (1) Na-acetate: Fe/ Mn carbonates, AVS, adsorbed and dissolved Fe; (2) hydroxylamine- $\mathrm{HCl}$ : lepidocrocite, hydrous ferric oxides (HFO); (3) Na-dithionite: goethite, haematite, akaganéite; (4) oxalate: magnetite; and (5) boiling $\mathrm{HCl}$ : poorly reactive sheet silicates. We also tested several pure minerals together with our samples. Several Fe-containing clay minerals were ordered from the Clay Minerals Society (3635 Concorde Pkwy, Suite 500, Chantilly, VA 20151-1110, USA) or from local traders (Krantz $\mathrm{GmbH}$, Bonn). Several Fe- oxides and hydroxides were manufactured as described by Schwertmann and Cornell (2000). All mineralogical compositions were confirmed by XRD.

Total dissolved Fe-concentrations of the extracts were measured with a Thermo iCE 3000 Series atomic absorption spectrometer (AAS) after ten- or hundred-fold dilution. The precision of the measurements was better than $\pm 2 \%$ (Standard deviation); the reproducibility of the extraction method for triplicate measurements was $10 \%$.

\section{Acid-volatile sulphide and chromium-reducible sulphur extraction}

On the same set of samples (frozen samples only), a sulphide extraction was performed following the standard methods of Canfield et al. (1986) and Fossing and Jørgensen (1989). The samples were covered with $50 \%$ ethanol, $16 \mathrm{ml}$ of $6 \mathrm{M} \mathrm{HCl}$ was added, and samples were distilled under nitrogen atmosphere for $1 \mathrm{~h}$. Hydrogen sulphide evolved from AVS was precipitated in $5 \% \mathrm{Zn}$ acetate traps as $\mathrm{ZnS}$. Following AVS extraction, Zn-acetate traps were replaced and $16 \mathrm{ml}$ of reduced $1 \mathrm{M}$ chromium chloride $\left(\mathrm{CrCl}_{2}\right)$ solution was added to the reaction vessel. Samples were heated and distilled for $1.5 \mathrm{~h}$. Hydrogen sulphide liberated from chromium-reducible sulphur (CRS; from pyrite and $\mathrm{S}^{0}$ ) was precipitated as $\mathrm{ZnS}$. Concentrations of $\mathrm{ZnS}$ suspended in both traps were analysed spectrophotometrically at $670 \mathrm{~nm}$ by the diamine complexation method using $N, N$-dimethyl-1,4-phenylenediamine-dihydrochloride (Cline 1969). Detection limit of the spectrophotometric analyses was $1 \mu \mathrm{M}$.

\section{X-ray absorption near-edge structure (XANES) spectroscopy}

XANES spectra were collected at the A1 beamline of the Hamburger Synchrotronstrahlungslabor (HASYLAB, Hamburg, Germany). Acquisition parameters were described in Meister et al. (2014). XANES spectra were collected at the Fe K-edge from 6960 to $8000 \mathrm{eV}$ with $5 \mathrm{eV}$ steps up to 7082 and $0.25 \mathrm{eV}$ between 7082 and $7152 \mathrm{eV}$. A reference foil of metallic $\mathrm{Fe}(0)$ was used for internal energy calibration of the monochromator (the first inflection point of the Fe K-edge was set at $7112.1 \mathrm{eV}$ ).

XANES spectra were processed and analysed using the Horae Athena free software (Newville 2001; Ravel and Newville 2005). Experimental spectra were normalized and fitted to a linear combination of standard spectra of $\mathrm{Fe}$ minerals using a least-square minimization procedure. The pre-edge centroid was calculated using the fitting procedure of Wilke et al. (2001) and using the free program Fityk (Wojdyr 2010) to determine the redox state of Fe in the samples. 


\section{Results}

\section{Sediment description}

Samples taken from Ktzi 202 (sampled between 627 and $638 \mathrm{~m}$ depth) consist of brittle and poorly cohesive sandstone. Only two samples (sample B2-1 and B4-2) are strongly lithified. The colour shows different reddish and beige domains. Some of the samples are very dark and easily disintegrate to sand. A millimetre-scale lamination is common. Thin sections show a well-sorted fine-grained sandstone (Fig. 2a, b). The structure is densely packed, grains are poorly rounded, and angular clasts show preferential orientation in the direction of the lamination (Fig. 2b). Mineral content is dominated by quartz with plagioclase, lithic fragments, opaque and sporadic single $50-\mu \mathrm{m}$-scale fibres (inset in Fig. 2c), possibly zeolites or sheet silicates (Fig. 2a-d). The matrix is microcrystalline, and its colour varies between light beige and dull with the lamination. Opaque domains are either rich in organic matter or opaque minerals (most likely Fe-oxides) (Fig. 2d).

In the SEM images (Fig. 3a), quartz, potassium feldspar, plagioclase, clay minerals and Fe-oxides were identified from semi-quantitative element abundances from EDX analyses. Also authigenic anhydrite cement, barite and single celestine crystals, all with a characteristic cleavage, were detected and confirmed by EDX. The main mineral phases, such as quartz and feldspar, are partly idiomorphic, usually with visible signs of dissolution and/or formation of authigenic cements on partly dissolved grains. The surfaces of quartz (Fig. 3b) and feldspar are coated by Fe-oxides, but also by clay minerals as shown in Fig. 3c, d (cf. also Förster et al. 2010). Clay minerals also grow in pits formed during dissolution, alteration and/or secondary precipitation processes (Fig. 3c).

\section{X-ray diffraction of the bulk sample}

Relative abundances of minerals were calculated from the ratios of the major peak areas normalized to $100 \%$ (Table 1a). The sandstone predominantly consists of quartz and plagioclase and occasionally contains analcime, an igneous zeolite. Several samples contain significant amounts of anhydrite. In particular, the strongly cemented sample B4-2 almost entirely consists of anhydrite. In some of the non-frozen samples, small amounts of gypsum were detected based on the $020(\mathrm{hkl})$ peak, while the 021 peak of gypsum interferes with the 100 peak of quartz. The 200 peak is also always present in these cases. However, gypsum in the non-frozen samples may be due to hydration of precursor anhydrite during sample storage. No carbonate minerals were detected. Several sheet silicates are present showing peaks at small $2 \theta$ angles. Illite (or muscovite) and chlorite indicate the best match with the peak distribution. A shoulder on the 001 peak (towards lower $2 \theta$ ) of chlorite at $6.2^{\circ} 2 \theta(d=14.3 \AA)$ may indicate the presence of smectite. A small peak at $24.16^{\circ} 2 \theta(d=3.68 \AA)$ matches the 012 peak of haematite, as reported by Förster et al. (2010).

\section{X-ray diffraction of the clay fraction}

Clay mineral separation and analysis revealed chloritegroup and mixed-layer clay minerals composed of illite and smectite in each sample. The samples exhibit similar diffraction patterns (Fig. 4). Quartz and feldspar are present due to disaggregation of detrital particles during the separation process. Other phases, which are not present in every sample, were identified as anhydrite, analcime and haematite. The most common phase shows the major reflection at $\sim 10 \AA$. It is a mixture of illite with interlayering of minor amounts of expandable clay minerals. Best fitting patterns in the diffractograms revealed an illite-smectite mixed phase defined by the formula $\left(\mathrm{K}_{0.66} \mathrm{Ca}_{0.33} \mathrm{Na}_{0.03}\right)\left(\mathrm{Al}_{1.78} \mathrm{Mg}_{0.22} \mathrm{Fe}_{0.01}\right)\left[\left(\mathrm{Si}_{3.43} \mathrm{Al}_{0.57} \mathrm{O}_{10}\right)\right.$ $(\mathrm{OH})_{2}$ ] (Gournis et al. 2008). Additionally, a montmorillonite (also smectite) is present. The interlayering type of smectite within the illite structure is mainly a sodium- and calcium-bearing component [montmorillonite $(\mathrm{Na}, \mathrm{Ca})_{0.33}$ $\left.(\mathrm{Al}, \mathrm{Mg})_{2}\left(\mathrm{Si}_{4} \mathrm{O}_{10}\right)(\mathrm{OH})_{2} * \mathrm{nH}_{2} \mathrm{O}\right]$, but other smectite interlayers cannot be excluded. The $10 \AA$ peak interferes with the major reflections of biotite; however, only in sample B4-3, a higher content of biotite was detected. Illite crystallinity varies from poor to well crystallized based on the Kübler index as full width at half maximum (FWHM; Table 1b).

The second most common phase is a chlorite-type mineral. The identified pattern fitting best represents the chemical composition of clinochlore $\left(\mathrm{Mg}_{2.96} \mathrm{Fe}_{1.698}\right.$ $\left.\mathrm{Al}_{1.275}\right)\left(\mathrm{Si}_{2.624} \mathrm{Al}_{1.376} \mathrm{O}\right)\left(\mathrm{OH}_{8}\right)$. Haematite is present in minority compared to clay minerals. It was identified by its major peak at $\sim 33.3^{\circ} 2 \theta$. Peak intensity of the haematite 110 peak $\left(35.7^{\circ} 2 \theta\right)$ increased after heating.

\section{Total, organic and inorganic carbon}

Total inorganic carbon content is near $0.1 \mathrm{wt} \%$ in several samples. The same samples show TOC around $0.2 \mathrm{wt} \%$ (Table 2). All other samples show TIC and TOC contents that are clearly below the detection limit. $\mathrm{S}$ was measured by CNS analysis in three samples, which is due to the presence of anhydrite or gypsum. In the anhydrite cemented sample B4-2, up to $6 \mathrm{wt} \% \mathrm{~S}$ was measured (Table 2). 

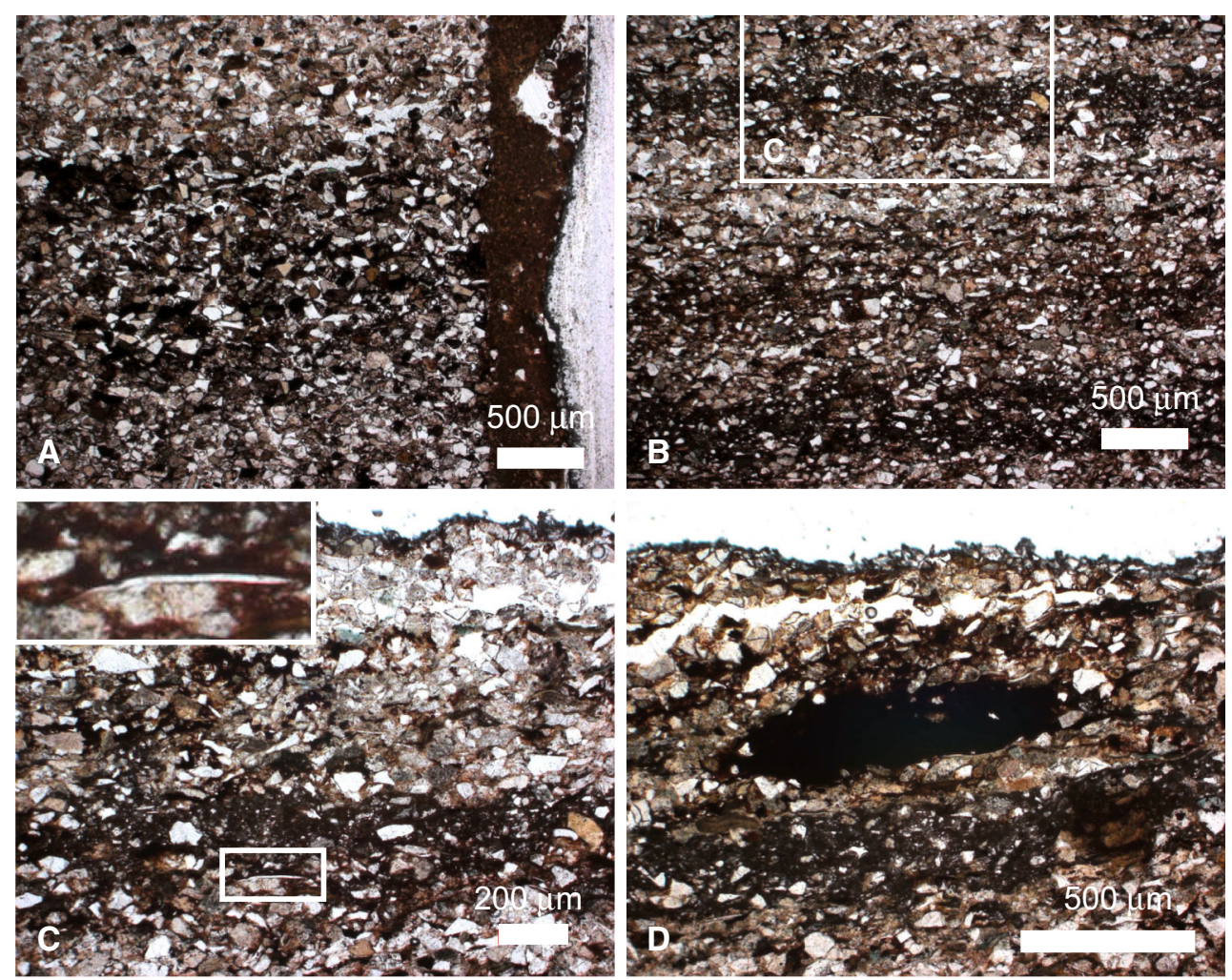

Fig. 2 Thin-section microphotographs of core sections from the Stuttgart Fm. at drill site Ktzi 202 displayed in plane polarized light. The sandstone is densely packed, grain supported, and angular clasts show preferential orientation. Mineral content is dominated by quartz

\section{X-ray fluorescence}

Total Fe-content analysed by XRF is in the range of $2-4$ wt\% (Table 3). Only sample B4-2 cemented by anhydrite contains less Fe. Samples containing anhydrite show high concentrations of calcium. Fe-to-Al ratios (wt/wt) vary between 0.4 and 0.7 .

\section{Sequential iron extraction}

The total concentration of reactive (extractable) Fe (sum of the five extraction steps without Fe-sulphides) is close to the total Fe-content for all samples and ranges from 2 to $100 \mathrm{mg} / \mathrm{g}$ (Table 4). Most of the extractable Fe is in the dithionite fraction (fraction III) and, in some of the samples, also in the boiling $\mathrm{HCl}$ fraction (fraction V). Concentration of fraction III Fe varies between 0.17 and 6.7 wt $\%$, while sheet silicate-bound $\mathrm{Fe}$ in most samples is around $0.2 \mathrm{wt} \%$. In samples B3-3a and B3-1, silicatebound $\mathrm{Fe}$ is strongly enriched (2.7 and $5.1 \mathrm{wt} \%)$. These samples also show the highest concentrations of total extractable $\mathrm{Fe}$ of 9.9 to $11.9 \mathrm{wt} \%$. This enrichment in $\mathrm{Fe}$ is not observed in XRF measurements and is probably due to inhomogeneities in crushed but not ground samples. with plagioclase, lithic fragments, opaque and fibrous crystals (inset). Interlayered are domains with fine-grained matrix. a Sample B2-3-2u; b sample B4-2-2; c inset in b; and d sample B4-2-2

Results from the standard minerals (Table 4) reveal that most minerals were extracted as predicted by Poulton and Canfield (2005). We highlight that besides the unreactive sheet silicates extracted by boiling $\mathrm{HCl}$, some sheet silicates are more reactive, in particular the smectite clays. Otherwise, results are unclear, such as for illite. These minerals also largely leach with the dithionite fraction, such that this fraction cannot be exclusively ascribed to goethite and haematite.

The total dissolved Fe-content in aerobically stored reservoir fluid was $0.0136 \mathrm{~g} / \mathrm{l}$. AAS measurements also showed $0.736 \mathrm{~g} / \mathrm{l} \mathrm{Ca}$ and $1.095 \mathrm{~g} / \mathrm{l} \mathrm{Mg}$ in this water sample.

\section{Acid-volatile sulphide and chromium-reducible sulphur}

AVS concentrations in all samples are below detection (Table 4). The samples contain between 6 and $15 \mathrm{ppm}$ (weight) CRS (Table 4; reported in ppm due to small values), which stoichiometrically represents $5-13 \mathrm{ppm}$ (weight) of pyrite-Fe. The highest pyrite content of $32.5 \mathrm{ppm}$ was measured in the strongly lithified sample B4-2. 

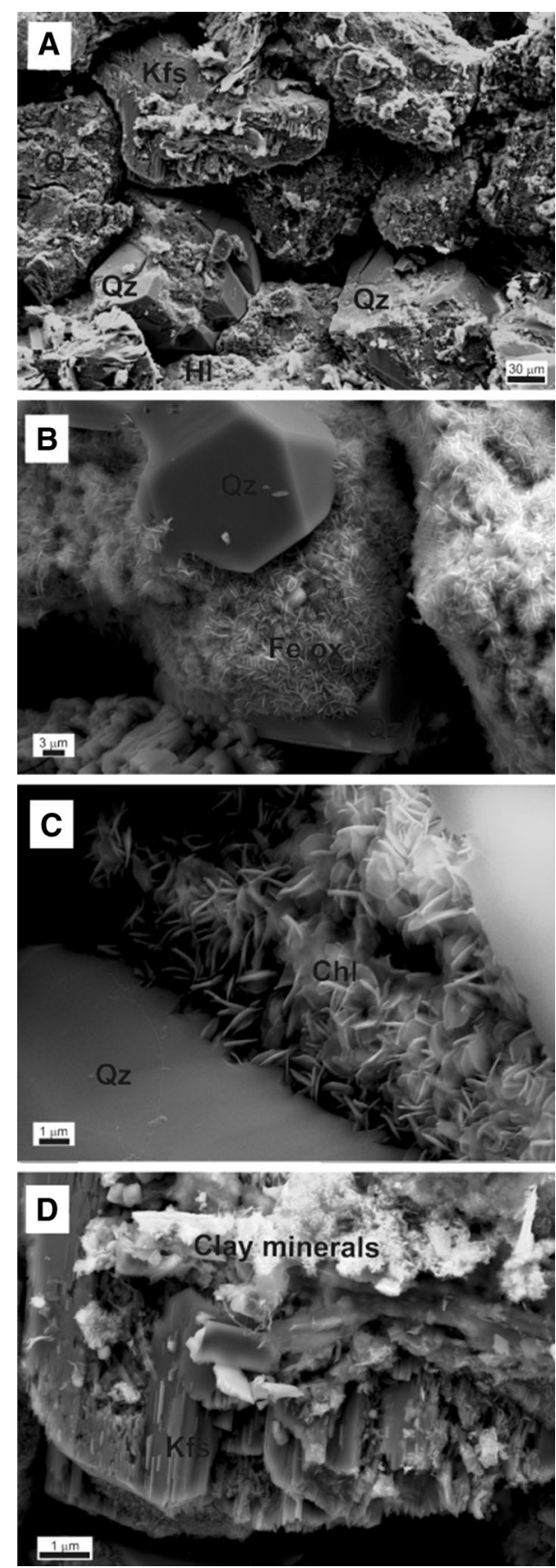

Fig. 3 a The SEM image of a weakly cemented sandstone of the Stuttgart Fm (Site Ktzi 202). b The surface of framework minerals (such as K-feldspar and quartz) is covered with Fe-oxides or clay minerals. c, d Clay minerals also fill cavities formed during dissolution or alteration process. $Q z$ quartz, $P l$ plagioclase, $K f s$ K-feldspar, $\mathrm{Chl}$ chlorite, $\mathrm{Hl}$ Halite

\section{XANES spectroscopy}

Linear combination fitting analyses of XANES spectra with a number of standard minerals (akaganéite, beidellite, chamosite, chlorite, illite, nontronite, goethite, haematite, saponite and zinnwaldite) show that illite and smectite are the most abundant $\mathrm{Fe}$-containing phases in the analysed rock samples (Fig. 5; Table 5). Results also show that chlorite and haematite are minor fractions in the sediment although chlorite is present in high abundance in X-ray diffractograms. Thus, the Fe-content in chlorite is very low. Redox states of Fe in the samples were calculated using the pre-edge of the XANES spectra and were shown to range between 2.6 and 2.8 .

\section{Discussion}

\section{Fe-mineralogy of Stuttgart Formation}

Before addressing possible Fe-related processes, we evaluate the different results presented above with respect to the dominating Fe-phase in the host rock. Both XRD and XANES spectroscopy clearly show that most of the Fe in the sandstones from Ketzin is bound to sheet silicate minerals. This outcome is consistent with the sequential extraction, taking into account that reactive sheet silicatebound $\mathrm{Fe}$ may also partially leach from the dithionite fraction (e.g. nontronite). Illite is the most abundant Fecontaining phase indicated by the abundance of illite-Fe from linear combination fits of the XANES spectra, suggesting that illite contributes more than half of the total $\mathrm{Fe}$ in the samples. Illite-Fe from XANES spectroscopy analysis correlates with the illite content determined by XRD (Fig. 6a). Illite-Fe does not positively correlate with the $\mathrm{Fe} /$ $\mathrm{Al}$ ratio (Fig. 6b), which could suggest that $\mathrm{Fe}$ is bound to another phase not containing Al. However, the poor or even anti-correlation could also be explained by $\mathrm{Fe}^{3+}$ substituting for $\mathrm{Al}(\mathrm{III})$ in the illite lattice (e.g. Seabaugh et al. 2006). A redox state of 2.6-2.8 was determined by analysing pre-edge peaks in the XANES spectra.

XRD analysis of the clay fraction allowed us to identify mixed-layered structures, in particular expandable layers of smectite within the illite structure and smectite and/or vermiculite within the chlorite structure. The smectite interlayers are confirmed by the XANES spectra, indicating up to $40 \%$ nontronite-bound $\mathrm{Fe}$. Nontronitebound $\mathrm{Fe}$ also explains the high $\mathrm{Fe}$-content in the dithionite fraction.

While the smectite layers in illite are clearly identified from the peak shift during saturation with ethylene glycol and subsequent heating to $550{ }^{\circ} \mathrm{C}$, the mixed layers in the chlorite structure may consist of vermiculite rather than smectite. A clear identification of the mixed layers in the chlorite structure is hampered by an atypical collapse of the 002, 003 and 004 hkl peaks during temperature treatment. Collapsing peaks have been described by Humphreys et al. (1989) for detrital and authigenic chlorite in late Triassic sandstones after heating the samples to $600{ }^{\circ} \mathrm{C}$, but the 


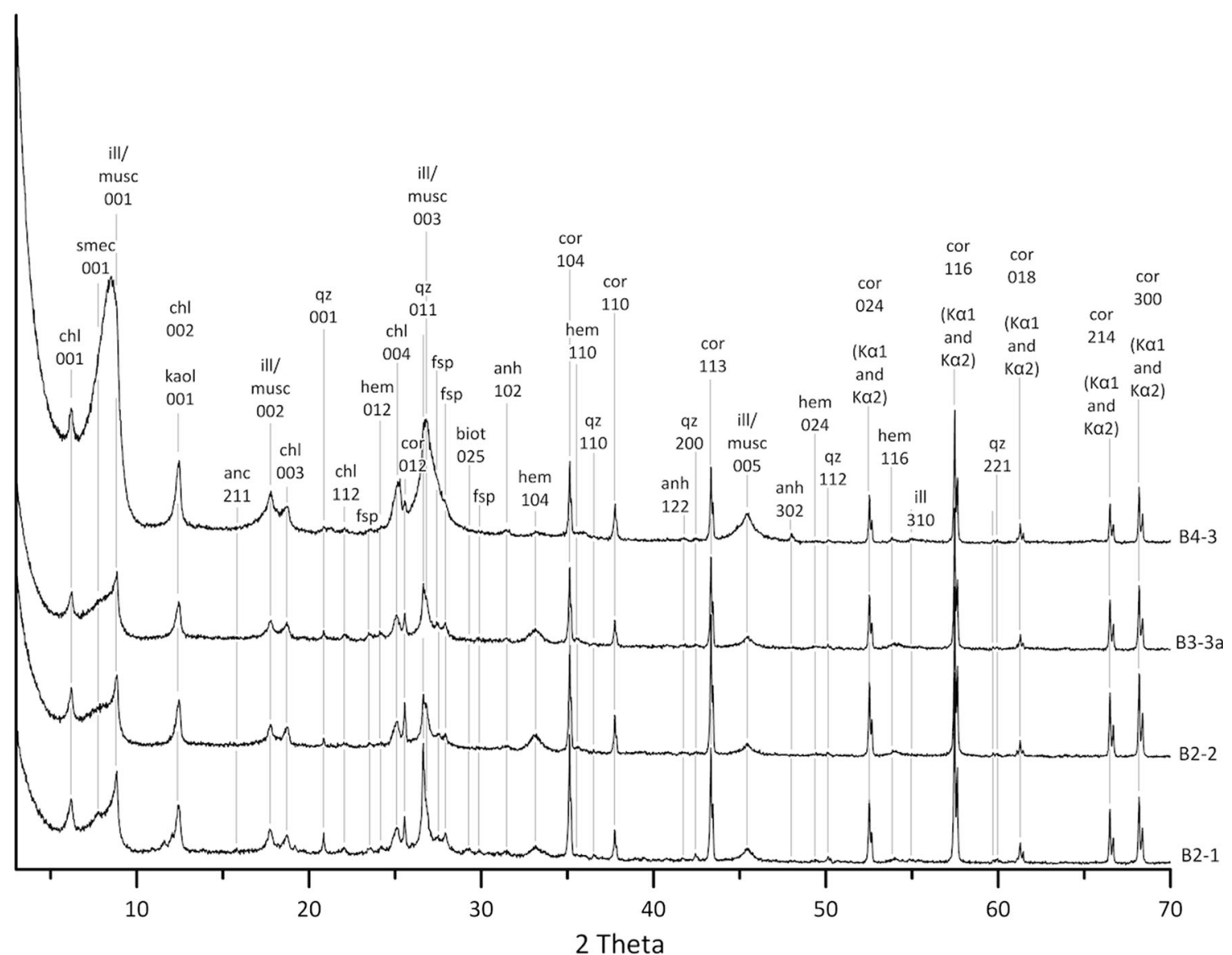

Fig. 4 Diffractograms of the clay mineral separates from drill site Ktzi 202 with peak identification and hkl indices: chlorite (chl), smectite (smec), illite (ill), muscovite (musc), kaolinite (kaol), analcime (anc), anhydrite (anh), quartz (qz), haematite (hem) and feldspars (fsp). Corundum (cor) is due to sample preparation
Table 2 Total inorganic carbon (TIC), total carbon (TC), total organic carbon (TOC), and total sulphur (TS) in Stuttgart Fm Sandstone from well Ktzi 202

\begin{tabular}{lcclll}
\hline Sample & Core depth $(\mathrm{m})$ & TIC $(\mathrm{wt} \%)$ & TC $(\mathrm{wt} \%)$ & TOC (wt\%) & TS (wt\%) \\
\hline $\begin{array}{l}\text { Refrigerated samples, freeze dried, } \\
\text { B2-2-2 }\end{array}$ & 627.5 & 0.09 & & & \\
B2-2-1 AB & 627.5 & 0.07 & 0.28 & 0.19 & 0.92 \\
B2-3-2 U & 628.7 & 0.09 & 0.33 & 0.21 & 3.33 \\
B3-1-2 & 629.8 & 0.01 & 0.04 & 0.24 & 0.73 \\
B3-3-3c-3 & 632.0 & 0.01 & 0.03 & 0.02 & 0.14 \\
B4-2-2 & 633.5 & 0.02 & 0.14 & 0.12 & 0.14 \\
Frozen Samples, freeze dried, ground $<10 \mu m$ & & & 0.02 \\
B2-2 & 627.5 & 0.10 & 0.31 & 0.21 & \\
B2-3 & 628.7 & 0.11 & 0.38 & 0.27 & 2.40 \\
B3-1 & 629.8 & 0.02 & 0.03 & 0.01 & 0.12 \\
B3-3a & 631.2 & 0.01 & 0.04 & 0.03 & 0.09 \\
B3-3c & 632.0 & 0.02 & 0.03 & 0.01 & 0.06 \\
B6-1 & 638.2 & 0.02 & 0.03 & 0.01 & 0.30 \\
Cemented and frozen, freeze dried, ground $<10 \mu m$ & & & 0.46 \\
B4-2 & 633.5 & 0.05 & 0.09 & 0.04 & 5.07 \\
\hline
\end{tabular}


Table 3 Total elemental composition of sandstone of the Stuttgart Fm analysed by X-ray fluorescence, well Ktzi 202

\begin{tabular}{|c|c|c|c|c|c|c|c|c|c|c|c|c|c|c|}
\hline Sample & $\begin{array}{l}\text { Core } \\
\text { depth }(\mathrm{m})\end{array}$ & $\begin{array}{l}\mathrm{Mg} \\
\text { (wt\%) }\end{array}$ & $\begin{array}{l}\mathrm{Al} \\
(\mathrm{wt} \%)\end{array}$ & $\begin{array}{l}\mathrm{Si} \\
(\mathrm{wt} \%)\end{array}$ & $\begin{array}{l}\mathrm{K} \\
(\mathrm{wt} \%)\end{array}$ & $\begin{array}{l}\mathrm{Ca} \\
(\mathrm{wt} \%)\end{array}$ & $\begin{array}{l}\mathrm{Ti} \\
\text { (wt\%) }\end{array}$ & $\begin{array}{l}\mathrm{Mn} \\
(\mathrm{wt} \%)\end{array}$ & $\begin{array}{l}\mathrm{Fe} \\
(\mathrm{wt} \%)\end{array}$ & $\begin{array}{l}\mathrm{Ni} \\
(\mathrm{wt} \%)\end{array}$ & $\begin{array}{l}\mathrm{Cu} \\
(\mathrm{wt} \%)\end{array}$ & $\begin{array}{l}\mathrm{Sr} \\
(\mathrm{wt} \%)\end{array}$ & $\begin{array}{l}\mathrm{Ba} \\
(\mathrm{wt} \%)\end{array}$ & $\begin{array}{l}\mathrm{Fe} / \mathrm{Al} \\
(\mathrm{wt} / \mathrm{wt})\end{array}$ \\
\hline \multicolumn{15}{|c|}{ Refrigerated samples, freeze dried, ground $<10 \mu \mathrm{m}$} \\
\hline B2-2-1 AB & 627.5 & 1.19 & 4.07 & 17.26 & 1.81 & 7.06 & 0.259 & 0.036 & 2.31 & 0.0027 & 0.0007 & 0.1257 & 0.0977 & 0.57 \\
\hline $32-2-2$ & 627.5 & 1.21 & 5.46 & 23.17 & 2.40 & 2.75 & 0.340 & 0.032 & 3.23 & 0.0030 & 0.0014 & 0.0476 & 0.0511 & 0.59 \\
\hline $32-3-2 \mathrm{U}$ & 628.7 & 1.23 & 5.64 & 24.04 & 2.38 & 2.39 & 0.337 & 0.034 & 2.64 & 0.0040 & 0.0028 & 0.0456 & 0.0371 & 0.47 \\
\hline $3-1-2$ & 629.8 & 0.98 & 5.96 & 25.34 & 2.38 & 0.72 & 0.350 & 0.017 & 3.11 & 0.0037 & 0.0004 & 0.0238 & 0.0391 & 0.52 \\
\hline $3-3 a-2$ & 631.2 & 0.79 & 5.65 & 22.90 & 2.38 & 0.43 & 0.337 & 0.014 & 4.26 & 0.0035 & 0.0006 & 0.0189 & 0.0356 & 0.75 \\
\hline $3-3 c-3$ & 632.0 & 0.94 & 6.09 & 26.13 & 2.42 & 0.69 & 0.290 & 0.016 & 2.18 & 0.0027 & 0.0009 & 0.0380 & 0.0366 & 0.36 \\
\hline $34-2-2$ & 633.5 & 1.50 & 7.79 & 26.18 & 3.35 & 0.33 & 0.445 & 0.019 & 4.10 & 0.0062 & 0.0013 & 0.0156 & 0.0422 & 0.53 \\
\hline \multicolumn{15}{|c|}{ Frozen Samples, freeze dried, ground $<10 \mu \mathrm{m}$} \\
\hline B2-2 & 627.5 & 1.14 & 4.30 & 18.22 & 1.92 & 5.32 & 0.337 & 0.032 & 2.90 & 0.0027 & 0.0008 & 0.0881 & 0.0258 & 0.67 \\
\hline B2-3 & 628.7 & 0.73 & 5.21 & 21.61 & 2.40 & 0.87 & 0.365 & 0.032 & 3.34 & 0.0036 & 0.0010 & 0.0239 & 0.0364 & 0.64 \\
\hline B3-1 & 629.8 & 0.68 & 5.51 & 21.45 & 2.19 & 0.44 & 0.313 & 0.017 & 3.99 & 0.0032 & 0.0008 & 0.0202 & 0.0391 & 0.72 \\
\hline B3-3a & 631.2 & 1.04 & 6.15 & 28.48 & 2.42 & 0.54 & 0.369 & 0.018 & 2.30 & 0.0047 & 0.0009 & 0.0204 & 0.0412 & 0.37 \\
\hline B3-3c & 632.0 & 0.66 & 5.60 & 22.11 & 2.33 & 0.81 & 0.258 & 0.017 & 2.38 & 0.0034 & 0.0006 & 0.0419 & 0.0606 & 0.43 \\
\hline B6-1 & 638.2 & 0.99 & 5.96 & 24.02 & 2.38 & 1.10 & 0.338 & 0.017 & 2.47 & 0.0049 & 0.0034 & 0.0286 & 0.0553 & 0.41 \\
\hline \multicolumn{15}{|c|}{ Cemented and frozen, freeze dried, ground $<10 \mu \mathrm{m}$} \\
\hline B4-2 & 633.5 & 1.20 & 3.52 & 15.66 & 1.39 & 10.95 & 0.285 & 0.020 & 1.48 & 0.0026 & 0.0008 & 0.1865 & 0.0301 & 0.42 \\
\hline
\end{tabular}

cause is not clearly known. The diffraction pattern of chlorite also depends on the Fe-content and the position of the $\mathrm{Fe}$ atoms in the silicate layer or the hydroxide sheet (Moore and Reynolds 1997). Usually, the relatively stable peak positions and some varying peak intensities for the 001, 002, 003 and 004 reflections during temperature treatment can be used as an indicator for the estimation of the Fe-content in chlorite (Moore and Reynolds 1997). However, due to the atypical reaction of the chlorite in our samples at $550{ }^{\circ} \mathrm{C}$, these peaks are destroyed. Based on the untreated diffraction patterns, the identified clinochlore fits best to the diffraction patterns exhibiting a Fe-content of $15.5 \mathrm{wt} \%$ and $\mathrm{Mg}$ content of $11.85 \mathrm{wt} \%$. XANES spectra only indicate subordinate levels of chlorite-bound Fe (max. $16.7 \%$ ). In contrast to smectites, chlorite mainly leaches in the boiling $\mathrm{HCl}$ fraction (Raiswell et al. 1994, and this study) and could contribute to parts of the illite-bound $\mathrm{Fe}$ to the high content of $\mathrm{Fe}$ in this fraction.

Chlorite is indicated by an increasing intensity and a slight peak shift upon heating from $6.226^{\circ} 2 \theta$ to $6.405^{\circ} 2 \theta$, which corresponds to a d-spacing reduction from 14.185 to $13.787 \AA$. This reaction of the 001 reflection of chlorite is typical and known from several examples (e.g. Hillier and Velde 1992; Humphreys et al. 1989; Moore and Reynolds 1997). It is explained by the dehydroxylation of the hydroxide sheet and attendant decrease in the d-spacing.
Chlorite in this study may be of both detrital or authigenic origins. Authigenic chlorite is commonly formed by the alteration of mafic igneous minerals during burial diagenesis (e.g. biotite; Meunier 2005). As detrital chlorite may form during grinding of the sample from minerals in the larger grain fractions, some chlorite in our samples may also be an artefact. This could explain the absence of chlorite from XANES spectrometry, which was treated separately from the clay mineral preparation.

A small peak at $3.68 \AA$ in the diffractograms suggests haematite in several of the samples. Also Förster et al. (2010) report the presence of minor amounts of haematite in the Stuttgart Fm. Fe-oxyhydroxides is often difficult to detect by XRD due to the extremely small crystal size and low refraction intensity. Also most concentrations in the sequential extraction are far below the detection limit of $5 \%$ for XRD. Fitting analysis of XANES spectra of the Ketzin samples confirms the low contribution of haematite to the total Fe-content. The large concentration of $\mathrm{Fe}$ in the dithionite fraction is not indicative of a high haematite content, since it co-elutes with smectite and possibly illite. Despite its low content, haematite may possibly be important as it forms coatings on sand grains (Fig. 3b), together with illite or smectite clays. Accordingly, haematite provides one of the most reactive $\mathrm{Fe}$-phases in the host rock. 
Table 4 Concentration of differently reactive Fe-phases in Stuttgart Sandstone and selected standard minerals from sequential extraction (wt\%; fractions I-V are defined in the main text, in the "Methods" section) and contents of acid-volatile sulphide (AVS) and chromiumreducible sulphur (CRS) in ppm (weight), well Ktzi 202

\begin{tabular}{|c|c|c|c|c|c|c|c|c|c|c|}
\hline Sample & Core depth $(\mathrm{m})$ & $\begin{array}{l}\text { I } \\
\text { (\% dry }\end{array}$ & $\begin{array}{l}\text { II } \\
\text { ight) }\end{array}$ & III & IV & $\mathrm{V}$ & Sum I-V & $\begin{array}{l}\text { AVS } \\
\text { (ppm dry }\end{array}$ & $\begin{array}{l}\text { CRS } \\
\text { weight) }\end{array}$ & Pyrite-Fe \\
\hline \multicolumn{11}{|c|}{ Refrigerated samples, freeze dried, ground $<10 \mu \mathrm{m}$} \\
\hline $\mathrm{B} 2-2-1 \mathrm{AB}$ & 627.5 & 0.024 & 0.043 & 1.708 & 0.065 & 0.228 & 2.07 & & & \\
\hline B2-2-2 & 627.5 & 0.031 & 0.064 & 4.043 & 0.110 & 0.352 & 4.60 & & & \\
\hline B2-3-2 U & 628.7 & 0.038 & 0.063 & 2.507 & 0.057 & 0.230 & 2.89 & & & \\
\hline B3-1-2 & 629.8 & 0.019 & 0.061 & 2.694 & 0.074 & 0.220 & 3.07 & & & \\
\hline B3-3a & 631.2 & 0.030 & 0.062 & 1.509 & 0.052 & 0.271 & 1.92 & & & \\
\hline B3-3c-3 & 632.0 & 0.019 & 0.045 & 1.429 & 0.032 & 0.254 & 1.78 & & & \\
\hline B4-2-2 & 633.5 & 0.034 & 0.085 & 3.123 & 0.059 & 0.233 & 3.53 & & & \\
\hline \multicolumn{11}{|c|}{ Frozen samples, crushed but not ground } \\
\hline B2-2 & 627.5 & 0.007 & 0.028 & 2.755 & 0.129 & 0.765 & 3.68 & - & 8.35 & 7.31 \\
\hline B2-3 & 628.7 & 0.012 & 0.025 & 1.831 & 0.109 & 0.219 & 2.20 & - & 7.27 & 6.36 \\
\hline B3-1 & 629.8 & 0.004 & 0.049 & 6.400 & 0.276 & 5.133 & 11.86 & - & 9.09 & 7.95 \\
\hline B3-3a & 631.2 & 0.002 & 0.039 & 6.668 & 0.464 & 2.677 & 9.85 & - & 6.08 & 5.32 \\
\hline B3-3c & 632.0 & 0.000 & 0.002 & 0.179 & 0.006 & 0.013 & 0.20 & - & 6.24 & 5.46 \\
\hline B6-1 & 638.2 & 0.001 & 0.003 & 0.212 & 0.006 & 0.016 & 0.24 & - & 14.60 & 12.78 \\
\hline \multicolumn{11}{|c|}{ Cemented, frozen, ground $<10 \mu \mathrm{m}$} \\
\hline B4-2 & 633.5 & 0.024 & 0.025 & 0.458 & 0.043 & 0.367 & 0.92 & - & 37.22 & 32.57 \\
\hline \multicolumn{11}{|c|}{ Standard minerals } \\
\hline Lepidocrocite $^{c}$ & & 0.02 & 1.37 & 1.62 & 0.00 & 0.00 & & & & \\
\hline Akaganéite $^{c}$ & & 0.02 & 0.24 & 10.44 & 0.00 & 0.00 & & & & \\
\hline Haematite $^{\mathrm{a}}$ & & 0.00 & 0.13 & 4.68 & 0.56 & 3.17 & & & & \\
\hline Haematite $^{c}$ & & 0.00 & 0.04 & 10.12 & 0.31 & 0.31 & & & & \\
\hline Goethite $^{\mathrm{a}}$ & & 0.00 & 0.03 & 3.56 & 0.73 & 3.59 & & & & \\
\hline Goethite $^{c}$ & & 0.01 & 0.04 & 8.78 & 0.53 & 0.20 & & & & \\
\hline Magnetite $^{\mathrm{a}}$ & & 0.02 & 0.13 & 2.17 & 9.78 & 3.53 & & & & \\
\hline Biotite $^{a}$ & & 0.19 & 0.29 & 0.08 & 0.20 & 2.06 & & & & \\
\hline Nontronite $^{\mathrm{a}}$ & & 0.01 & 0.07 & 0.96 & 0.00 & 0.00 & & & & \\
\hline Nontronite $^{\mathrm{b}}$ & & 0.00 & 0.01 & 0.61 & 0.39 & 1.14 & & & & \\
\hline Saponite $^{\mathrm{b}}$ & & 0.00 & 0.01 & 0.02 & 0.00 & 0.00 & & & & \\
\hline Zinnwaldite $^{\mathrm{a}}$ & & 0.01 & 0.01 & 0.02 & 0.00 & 0.01 & & & & \\
\hline Riebeckite $^{\mathrm{a}}$ & & 0.01 & 0.01 & 0.35 & 0.02 & 0.05 & & & & \\
\hline Chamosite $^{\mathrm{a}}$ & & 0.47 & 0.54 & 0.73 & 1.18 & 3.30 & & & & \\
\hline Chlorite $^{\mathrm{b}}$ & & 0.02 & 0.02 & 0.02 & 0.01 & 0.10 & & & & \\
\hline Siderite $^{\mathrm{a}}$ & & 3.58 & 0.95 & 0.95 & 0.15 & 0.10 & & & & \\
\hline Pyrite $^{\mathrm{a}}$ & & 0.40 & 0.05 & 0.10 & 0.08 & 0.09 & & & & \\
\hline Greigite $^{c}$ & & 3.91 & 0.20 & 0.08 & 0.28 & 0.04 & & & & \\
\hline Greigite, wet ${ }^{\mathrm{c}}$ & & 0.78 & 0.00 & 0.00 & 0.00 & 0.00 & & & & \\
\hline Green rust, wet ${ }^{\mathrm{c}}$ & & 0.18 & 0.02 & 0.01 & 0.00 & 0.00 & & & & \\
\hline
\end{tabular}

Values larger than 0.1 are highlighted in bold

${ }^{\text {a }}$ Krantz BmbH

b Clay Mineral Society

c Synthetic

Other minerals, such as feldspar, may only contain traces of $\mathrm{Fe}$, while quartz anhydrite, gypsum and halite do not contribute any Fe to the reservoir rock. Although analcime itself does not contain $\mathrm{Fe}$, zeolites are known for their ability to bind Fe (Pirngruber et al. 2004). 

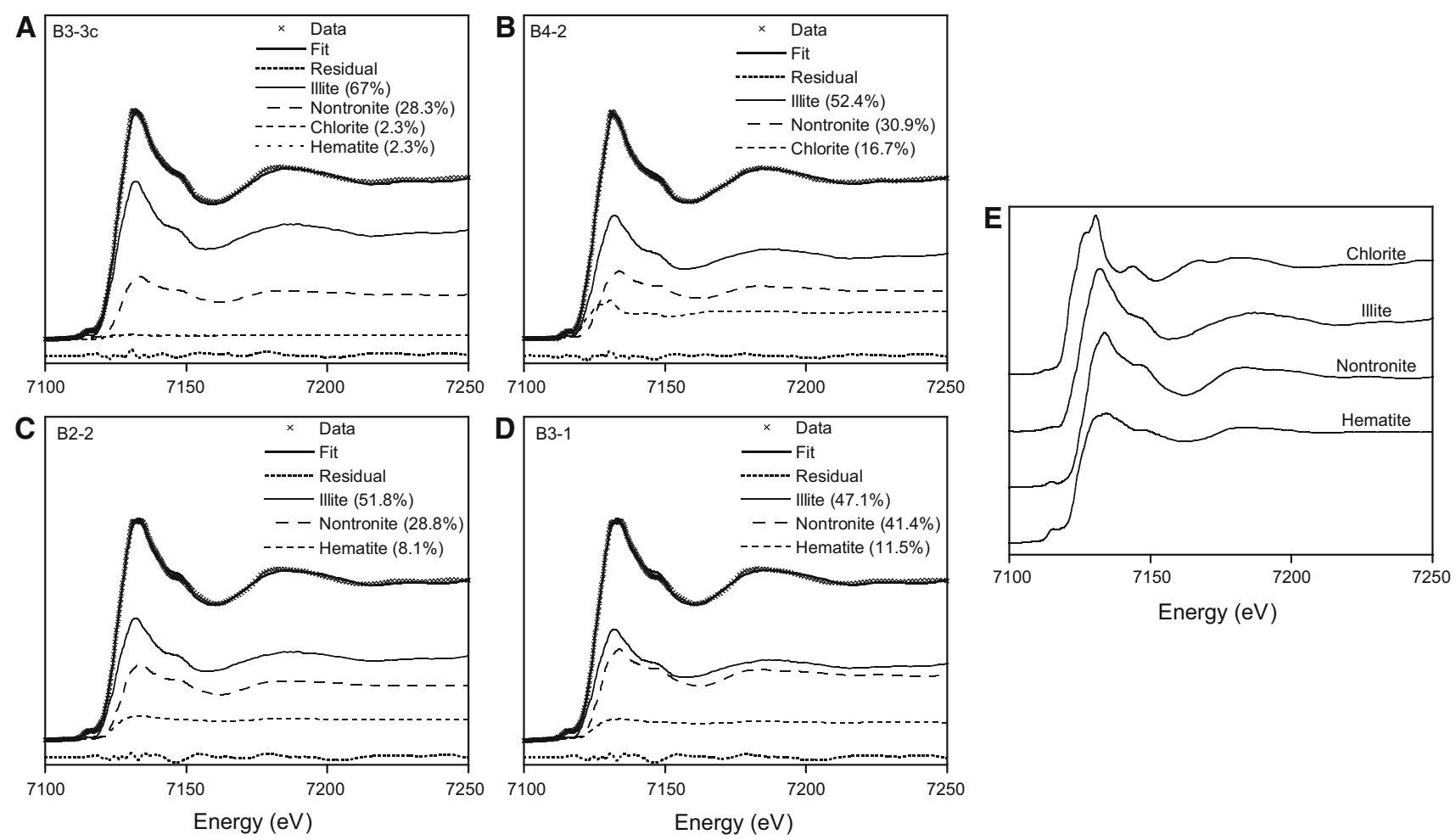

Fig. 5 a-d Linear combination fits (bold line) of standard spectra to measured spectra (crosses) of samples B2-2, B3-1, B3-3c, and B4-2. the best fit. e XANES spectra of standard minerals chlorite, illite, Percentages indicated the relative abundances of $\mathrm{Fe}$-phases based on nontronite and haematite

Table 5 Relative fractions of Fe-phases based on linear combination fits of XANES spectra of several standard minerals to spectra from Ketzin cores samples (well Ktzi 202)

\begin{tabular}{|c|c|c|c|c|c|c|c|c|}
\hline Sample & Core depth (m) & Total Fe (mg/g) & Illite & Nontronite $(\mathrm{CV})$ & Chlorite & Haematite & Reduced $\chi^{2}$ & Calculated redox state \\
\hline \multicolumn{9}{|c|}{ Refrigerated samples, freeze dried, ground $<10 \mu \mathrm{m}$} \\
\hline B2-2-1 AB & 627.5 & 20.68 & 0.584 & 0.244 & 0.041 & 0.13 & 0.000943 & 2.7 \\
\hline B2-2-2 & 627.5 & 46.01 & 0.564 & 0.372 & 0.064 & 0.064 & 0.000144 & 2.7 \\
\hline B2-3-2 U & 628.7 & & 0.602 & 0.273 & 0.031 & 0.094 & 0.0000949 & 2.7 \\
\hline B3-1-2 & 629.8 & 30.68 & 0.631 & 0.288 & 0 & 0.081 & 0.0000978 & 2.8 \\
\hline B3-3a-2 & 631.2 & & 0.556 & 0.642 & 0.102 & 0 & 0.0001016 & 2.8 \\
\hline B3-3c-3 & 632.0 & & 0.651 & 0.289 & 0.063 & 0 & 0.000898 & 2.7 \\
\hline B3-3c-3 & 632.0 & & 0.659 & 0.271 & 0.07 & 0 & 0.0000947 & 2.6 \\
\hline B4-2-2 & 633.5 & & 0.63 & 0.34 & 0 & 0.031 & 0.0000982 & 2.7 \\
\hline \multicolumn{9}{|c|}{ Frozen Samples, freeze dried, ground $<10 \mu \mathrm{m}$} \\
\hline B2-2 & 627.5 & 36.84 & 0.518 & 0.35 & 0 & 0.131 & 0.0001204 & 2.7 \\
\hline B2-3 & 628.7 & 21.96 & 0.617 & 0.258 & 0 & 0.125 & 0.0000874 & 2.7 \\
\hline B3-1 & 629.8 & 118.63 & 0.471 & 0.414 & 0 & 0.115 & 0.0001215 & 2.8 \\
\hline B3-3a & 631.2 & & 0.6 & 0.285 & 0.0066 & 0.049 & 0.0001104 & 2.8 \\
\hline B3-3c & 632.0 & 2.01 & 0.67 & 0.283 & 0.023 & 0.024 & 0.000088 & 2.8 \\
\hline B6-1 & 638.2 & & 0.617 & 0.0324 & 0 & 0.059 & 0.0001172 & 2.8 \\
\hline \multicolumn{9}{|c|}{ Cemented and frozen, freeze dried, ground $<10 \mu \mathrm{m}$} \\
\hline B4-2 & 633.5 & 9.17 & 0.524 & 0.309 & 0.167 & 0 & 0.00000875 & 2.7 \\
\hline
\end{tabular}


Fig. 6 a Relative abundance of illite from XRD of the bulk sample plotted versus abundance of illite-Fe based on XANES. b $\mathrm{Fe} / \mathrm{Al}$ ratio (from $\mathrm{XRF}$ ) versus abundance of illite-Fe based on XANES

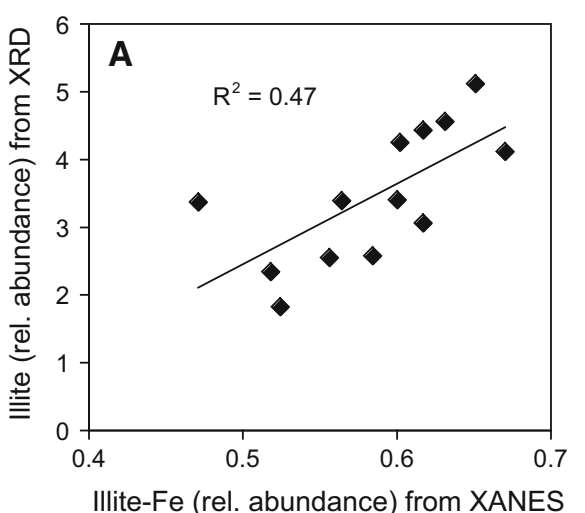

\section{Origin of the iron and past Fe-cycling}

The content of $\mathrm{Fe}$ of up to $4 \mathrm{wt} \%$ in the fluvial sandstone of the Stuttgart Fm. is relatively high. This high Fe-content in Triassic fluvial sandstone is commonly explained by weathering under temporarily arid climate, causing oxidizing conditions during vadose zone diagenesis (e.g. Kozur and Bachmann 2010; Förster et al. 2010). The humid intervals during the Carnian (Kozur and Bachmann 2010) may have provided temporarily phreatic zones in which anoxic conditions could have prevailed leading to a mobilization and redistribution of Fe-phases (Förster et al. 2010). Under anoxic conditions, Fe-reducing bacteria would have used $\mathrm{Fe}$ (III) from minerals as electron acceptor to degrade relatively fresh and reactive organic matter. Iron became mobilized as $\mathrm{Fe}$ (II) and was re-oxidized as haematite coatings on the sand grains at redox boundaries within the laminated sediment (Busigny and Dauphas 2007; Förster et al. 2010). This explanation is in line with relatively low organic carbon contents, allowing for temporarily oxic conditions. Where the sediment is more finegrained and adjacent to coal seams, reductive conditions were maintained. These zones are recognized by beige or green reduction spots within the otherwise red sandstone. A similar explanation for early $\mathrm{Fe}$ mobilization has been proposed for aeolian Navajo Sandstone on the Colorado Plateau (Utah, Colorado, Arizona and New Mexico; Chan et al. 2000, 2005). Possibly acidic pore water in forest soil or in freshwater swamps, as they prevailed temporarily during the Carnian Pluvial Episode (Kozur and Bachmann 2010), may have contributed to leaching Fe. Humic substances available surrounding these zones could have acted as chelators for the otherwise insoluble Fe(III) (cf. Lipson et al. 2010).

Overall, the haematite coating is a minor phase in the samples. More quantitatively important are the illitesmectite components. Illite is a weathering product under predominantly arid conditions, whereas smectites or illite-smectite mixed layers are likely the product of seasonally humid conditions during the Carnian (see, e.g. Robert and Kennett 1994; and references therein). It is known that Fe may change its redox state in situ (Kostka and Luther III 1994) such that also silicate-bound $\mathrm{Fe}$ may have undergone redox changes in the past. A predominantly three-valent state supports that depositional and early diagenetic conditions were largely oxic, but perhaps, temporarily anoxic, supporting episodic pluvial conditions.

Besides, illitization also could have occurred later during burial. Maximum burial temperatures of $85-135{ }^{\circ} \mathrm{C}$ (Norden and Frykman 2013) were reached, while the maximum burial depth for the Upper Keuper sediments was about $1200 \mathrm{~m}$ (Förster et al. 2006; the Stuttgart Fm. is Middle Keuper; thus, max. burial depth was a bit higher). However, illite crystallinity (Table $1 \mathrm{~b}$ ) is too variable to give a clear indication of burial overprint and timing of illite formation.

\section{Ongoing iron and sulphur cycling}

At present, in the buried Stuttgart Fm., Fe-reducing activity is low, despite the fact that there is enough reactive $\mathrm{Fe}$ present in the rock. XANES spectra indicate a predominantly oxidized state of the Fe. Also low concentrations of pyrite suggest that abiotic or biotic Fe-reduction is not an important process in the Stuttgart Fm. and neither was it in the past. Since the pore fluid is sulphate-rich brine, formation of sulphide by sulphate reduction is also most likely limited by the low availability of organic matter as electron donor. The ternary diagram of relative abundances of total $\mathrm{Fe}$, TOC and CRS (Fig. 7) shows that Fe-reduction is limited by the availability of organic carbon and sulphide. With an organic carbon and energy source available, microbial Fe-reduction (Eq. 1) could be a dominant anaerobic process under the current geochemical conditions in the Stuttgart Fm. as it is one of the most energyefficient terminal electron-accepting pathways (Lovley and Phillips 1987). 
$2 \mathrm{Fe}_{2} \mathrm{O}_{3}+\mathrm{CH}_{2} \mathrm{O}+8 \mathrm{H}^{+} \rightarrow 4 \mathrm{Fe}^{2+}+\mathrm{CO}_{2}+5 \mathrm{H}_{2} \mathrm{O}$

Despite the delivery of "fresh" organic matter, this process would be kinetically limited by the defined reactivity of Fe-mineral surfaces (Afonso and Stumm 1992), such that, for kinetic reasons, sulphate reduction (Eq. 2) could likewise be a dominating pathway in sulphate-rich brine (Hansel et al. 2015):

$\mathrm{SO}_{4}^{2-}+2 \mathrm{CH}_{2} \mathrm{O} \rightarrow \mathrm{HS}^{-}+2 \mathrm{HCO}_{3}^{-}+\mathrm{H}^{+}$

Reactive Fe-oxides would then undergo reductive dissolution coupled to sulphide oxidation:

$8 \mathrm{FeOOH}+9 \mathrm{HS}^{-}+7 \mathrm{H}^{+} \rightarrow 8 \mathrm{FeS}+\mathrm{SO}_{4}^{2-}+12 \mathrm{H}_{2} \mathrm{O}$

The precipitation of Fe-sulphide may cause problems by reducing permeability of the reservoir rock (Zettlitzer et al. 2010; Pellizzari et al. 2017) during injection.

Together with the consumption of one mole of protons, this reaction results in an increase in alkalinity and may therefore also induce carbonate precipitation (e.g. Wehrmann et al. 2009). In addition, following Wächtershäuser's (1988) reaction, a loss of ferrous $\mathrm{Fe}$ from $\mathrm{FeS}$ with the release of $\mathrm{H}_{2}$ may lead to alteration of $\mathrm{FeS}$ to pyrite $\left(\mathrm{FeS}_{2}\right.$; Wilkin and Barnes 1996):

$2 \mathrm{FeS}+2 \mathrm{H}^{+} \rightarrow \mathrm{FeS}_{2}+\mathrm{Fe}^{2+}+\mathrm{H}_{2}$

This reaction can drive a cryptic sulphur cycle (Holmkvist et al. 2011) and, at the same time, also consumes protons, which contributes to an increase in alkalinity.

As shown by Canfield et al. (1993) and a recent molecular study from marine sediments by Reyes et al. (2016), microbially driven Fe-reduction may outcompete sulphur cycling at relatively low substrate levels

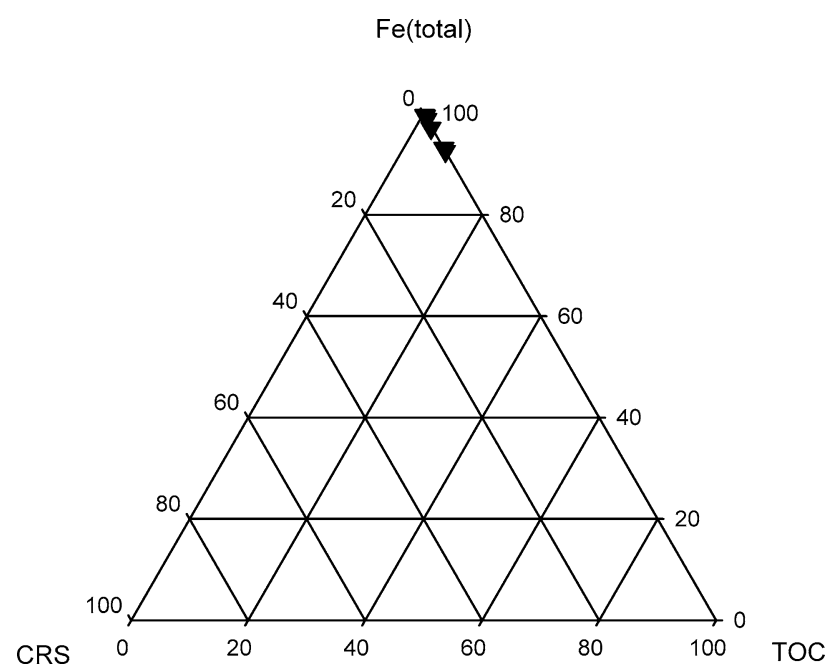

Fig. 7 Ternary diagram showing relative abundances of total Fe, TOC and CRS. Results show that Fe-reduction is limited by the availability of organic carbon and sulphide (presumably low enough that the reactivity of Fe-mineral surfaces is not kinetically limiting) resulting in an excess production of $\mathrm{Fe}$ (II) (up to $760 \mu \mathrm{M}$ dissolved $\mathrm{Fe}$ in Ketzin pore water) over sulphide.

Our finding of low Fe-reducing activity is supported by results from a microbial community study in the same sandstones using the 16S rDNA fingerprinting method (Wandrey et al. 2011a, 2011b). According to these studies, the microbial abundance in the rock material is very low and only small amounts of DNA could be extracted. Sequences, which belong to chemoheterotrophs related to Burkholderia fungorum (97\% similarity), Agrobacterium tumefaciens (95\% similarity) as well as facultative chemolithoautotrophs related to Hydrogenophaga (100\% similarity), were identified. All groups are able to oxidize either organic molecules or hydrogen to gain energy (Wandrey et al. 2011a).

\section{Effect of borefluid}

Organic matter introduced by the drilling mud (Wandrey et al. 2010) could trigger microbial processes in the nearwell area. Pellizzari et al. (2017) demonstrated that injectivity loss at the $\mathrm{CO}_{2}$ storage site in Ketzin was related to microbially mediated processes. Exposure to organics (drill mud components and biodegradation products) caused changes in autochthonous microbial community and acceleration in activity of some microbial groups. A total of $10^{6}$ cells ml ${ }^{-1}$ (similar to the cell abundance in marine sediments with low TOC or at greater burial depth, $>100$ m; e.g. D'Hondt et al. 2004; Parkes et al. 2005) was detected in well fluids from a depth of $647 \mathrm{~m}$ that were influenced by organic drilling mud (Morozova et al. 2011). Fluorescent in situ hybridization analyses revealed a high abundance of sulphate-reducing bacteria in these fluids (Pellizzari et al. 2016). Furthermore, fermentative halophilic bacteria, which were related to species of Halanaerobium, and sulphate-reducing bacteria distantly related to species of Desulfohalobium were detected by genetic fingerprinting. In this case, it can be clearly demonstrated that the substrate is no longer limited, while $\mathrm{Fe}(\mathrm{III})$ becomes limiting as electron acceptor, such that sulphate reduction becomes the dominant terminal electron-accepting process. As a result, injectivity loss due to FeS precipitation was recorded (Zettlitzer et al. 2010).

Furthermore, methane was detected in a fluid sample from a depth of $647 \mathrm{~m}$ after performing a $\mathrm{N}_{2}$ injection (Zimmer et al. 2011). The $\mathrm{N}_{2}$ injections $\left(\mathrm{N}_{2}\right.$ lifts) were performed to remove organic-rich drill mud and restore the injectivity (Zettlitzer et al. 2010) in order to prepare the well for $\mathrm{CO}_{2}$ injection. The formation water affected by the bore fluid contained $64 \mathrm{ml}$ of dissolved gas/l of fluid being composed of $90 \% \mathrm{~N}_{2}, 4 \% \mathrm{CO}_{2}, 0.44 \% \mathrm{He}, 0.22 \% \mathrm{CO}$, 
$0.18 \% \mathrm{H}_{2}$ and $5.7 \% \mathrm{CH}_{4}$ (Zimmer et al. 2011). The fluid also contained acetate, with both $\mathrm{H}_{2}$ and acetate providing intermediates for methanogenesis. Indeed, methanogenic archaea were detected in high numbers by fluorescence in situ hybridization (FISH) in the well fluids (Morozova et al. 2011).

During $\mathrm{CO}_{2}$ injection, methane was transported with the gas plume towards the monitoring wells. Zimmer et al. (2011) showed that a considerable amount of methane was still present in the $\mathrm{N}_{2}$-rich gas from the $\mathrm{N}_{2}$ lift dissolved in the formation water even after a travel time of nine months within the reservoir (before the arrival of the $\mathrm{CO}_{2}$ ). This suggests that methane was not readily consumed by anaerobic methane oxidation (AOM) neither through sulphate reduction (Boetius et al. 2000; Eq. 5) nor through Feoxide reduction (Wankel et al. 2012; Eq. 6). Iron reduction coupled to AOM is energetically more favourable than sulphate reduction coupled to AOM (Riedinger et al. 2014), and thus, the latter process would likely prevail under low substrate availability.

$$
\begin{aligned}
& \mathrm{CH}_{4}+\mathrm{SO}_{4}^{2-} \rightarrow \mathrm{HCO}_{3}^{-}+\mathrm{HS}^{-}+\mathrm{H}_{2} \mathrm{O} \\
& \mathrm{CH}_{4}+8 \mathrm{FeO}(\mathrm{OH})+15 \mathrm{H}^{+} \rightarrow \mathrm{HCO}_{3}^{-}+8 \mathrm{Fe}^{2+}+13 \mathrm{H}_{2} \mathrm{O}
\end{aligned}
$$

AOM may be inhibited due to high salinity of the brine, an effect that is known from highly saline or alkaline environments (Kulp et al. 2007; Boetius and Joye 2009). Accordingly, we could expect that freshening of the pore fluid near the injection well by lower-salinity drilling fluids (Würdemann et al. 2010) and the subsequent reduction of salinity in the rock pores may stimulate microbial activity (Würdemann et al. 2010). Despite its low energy yield and long adaptation times (Nauhaus et al. 2007), AOM acts as an important sink of sulphate and methane in many marine sediments and could likewise establish a zone of AOM within $\mathrm{CO}_{2}$ storage reservoirs. AOM coupled to sulphate or $\mathrm{Fe}$-reduction would efficiently contribute to an increase in alkalinity (Eqs. 5 and 6). AOM zones are well known for the formation of hard lithified layers of carbonate, in particular dolomite (Meister et al. 2007; 2011; Meister 2015).

\section{Possible effects of $\mathrm{CO}_{2}$ injection on Fe-cycling}

Effects of $\mathrm{CO}_{2}$-injection on the mineralogical composition of the reservoir rock were reported by Bock et al. (2013) in a study of drill-cores recovered from the Ketzin site before and four years after $\mathrm{CO}_{2}$ injection. Even though the changes in the bulk-rock composition were only slight, small-scale studies focused on the mineral surface reactions revealed alteration of $\mathrm{Fe}$-rich grain coatings after the exposure to supercritical $\mathrm{CO}_{2}$. A transformation of haematite to goethite coatings in the $\mathrm{CO}_{2}$-penetrated rocks was noticed (Bock et al. 2013). SEM and EMPA analyses also revealed authigenic poikilitic dolomite not observed before $\mathrm{CO}_{2}$-injection. Small aggregates are composed of a core of dolomite-ankerite solid solution and mantled by siderite and calcite, consistent with the high $\mathrm{Fe}$-content measured in the Stuttgart Fm. (Förster et al. 2010). Siderite may form upon increasing availability of $\mathrm{Fe}(\mathrm{II})$ due to Fe-reduction. Siderite would replace the precursor dolomite due to its much lower solubility, even under acidic conditions (Bock et al. 2013). The presence of siderite is also an indicator for non-sulphidic conditions (cf. Rodriguez et al., 2000; see compilation in Meister 2015).

While $\mathrm{Fe}(\mathrm{III})$ is more soluble under acidic conditions, $\mathrm{CO}_{2}$-injection per se would not drive Fe-reduction. Even in a dissolved state, Fe-reduction would not occur under electron donor limitation. Potential electron donors could be added as organic matter injected together with the $\mathrm{CO}_{2}$. Also, bio-available organic compounds could be leached from unreactive solid-phase organic matter by supercritical $\mathrm{CO}_{2}$. For example, Scherf et al. (2011) showed a mobilization of up to $39 \%$ of sedimentary organic matter by the flow of supercritical $\mathrm{CO}_{2}$ in laboratory flow-through experiments with undisturbed inner cores of Ketzin sandstone samples, obtained after the removal of drill mud contaminations. In addition, low molecular weight organic acids such as formate, acetate and propionate as well as butanoic, pentanoic, lactic, pyruvic, glycolic and gluconic acid were extracted to a sum of up to $538 \mu \mathrm{g} / \mathrm{kg}$ reservoir rock due to exposure to supercritical $\mathrm{CO}_{2}$. The mobilized organic substrate could serve as additional feedstock for the microorganisms and thus induce their growth (Scherf et al. 2011) for a certain time, even if the $\mathrm{CO}_{2}$ loses its solvent properties due to a pressure decrease or dilution effects.

Scherf et al. (2011) also detected intact polar lipid fatty acids, indicating a bacterial origin. Pellizzari et al. (this volume) observed that an increased availability of organic carbon led to a changed autochthonous microbial community of the rock samples exposed to 50 bar $\mathrm{CO}_{2}$. Facultative anaerobic organisms affiliated to the genera Ralstonia, Burkholderia and Variovorax, which are capable of nitrate reduction (King 2006; Tiemeyer et al. 2007; Im et al. 2010), became dominant. Even though the detected DNA sequences might represent uncultured species of these genera, known representatives are adapted to a $\mathrm{CO}_{2}$ atmosphere, and for example, Ralstonia can change to an organotrophic metabolism when organic substrates are available (Park et al. 2011).

These studies show that the amount of organic matter derived from remobilization of TOC could drive significant microbial activity presumably resulting in the reduction of parts of the reactive Fe-coatings and, besides, reduce injectivity through biofilm formation. Even though the 
amount of organic carbon present in the rock would not be sufficient to reduce significant amounts of the total $\mathrm{Fe}$ content of the sandstone, these studies imply that supply of a significant amount of organic matter with the $\mathrm{CO}_{2}$ could stimulate microbial growth, thereby inducing diagenetic processes in the reservoir.

\section{Long-term evolution and reactivity of silicates}

Based on the discussion above, the major portion of the $\mathrm{Fe}$ occurs in the sheet silicate fraction. The silica-bound Fe can be redox active, but it is still a matter of ongoing discussion whether and how $\mathrm{Fe}$ is incongruently leached from silicate phases. In smectite and illite, these reactions are estimated to occur on 1- to 10-million-year timescales (Canfield 1989; Canfield et al. 1992). Fe release may be accelerated in the presence of sulphide leading to the precipitation of pyrite. Also more $\mathrm{Fe}$ could be leached through silicate alteration due to acidification by $\mathrm{CO}_{2}$ (Lichtschlag et al. 2015). In situ reduction of Fe in clay minerals under reducing conditions has been demonstrated (Kostka and Luther III 1994; Lee et al. 2006; Ribeiro et al. 2009; Stucki and Kostka 2006), and this process can be catalysed by microbes. Santelli et al. (2001) observed accelerated leaching due to oxidative leaching of Fe from silicates in which Fe occurs in the reduced state. However, this would rather be under oxic conditions and would cause a lowering of the $\mathrm{pH}$. "Longer"-term experiments over a duration of up to 21 months with rocks of the Stuttgart Fm. at Ketzin exposed to synthetic reservoir brine with a $\mathrm{CO}_{2}$ pressure of 55 bar were performed by Fischer et al. (2010, 2011, 2013). Already after this (relatively short) time period, signs of alteration were observed, such as anhydrite dissolution and corrosion textures on feldspar. Despite corrosion features, also neo-formed albite was observed.

Independent of Fe-oxidation or reduction, silicate alteration itself (e.g. alteration of plagioclase, volcanic glass or mafic minerals) could significantly contribute to $\mathrm{pH}$ buffering. Even though silicates react slowly, they may over long time periods be the dominating $\mathrm{pH}$-neutralizing process. Such a long-term behaviour is difficult to predict. Silicate alteration is likely to be a strong $\mathrm{pH}$-buffering process as it can be observed in naturally occurring $\mathrm{CO}_{2}$ reservoirs, such as within the methanogenic zones of deepsea sediments (cf., Wallmann et al. 2008; Meister et al. 2011; Scholz et al. 2013; Wehrmann et al. 2016) or in basalt (e.g. Shishkina et al. 2010; Shilobreeva et al. 2011). Also model calculations could be used to predict such longterm behaviour (e.g. Chan et al. 2007). Perhaps, selective leaching of Fe may also enhance the silicate dissolution or alteration rates (cf. Santelli et al. 2001). Long-term monitoring studies and the study of natural analogues (e.g. Bickle and Kampman 2013) will be necessary in order to trace such slow proceeding changes of sediment composition, mineralogy and fluid chemistry within the $\mathrm{CO}_{2}$ reservoir.

\section{Conclusions}

The rock samples taken during deep drilling at the Ketzin pilot test site show a relatively high total Fe-content of up to $4 \mathrm{wt} \%$. Most of the $\mathrm{Fe}$ is present in the sheet silicate fraction, such as smectite-illite mixed-layer clay minerals and possibly chlorite, and only minor amounts occur as haematite coatings. The redox state of the Fe is 2.7-2.8 and therefore rather high, but still not entirely oxidized. This composition largely reflects the mixed redox state of the $\mathrm{Fe}$ partitioned in the clay mineral phases, consistent with the arid to seasonally humid conditions in the depositional environment in the Triassic (Kozur and Bachmann, 2010) and perhaps minor late diagenetic alteration. The reduced, sulphide-bound Fe-fractions (acid-volatile sulphide and chromium-reducible sulphur fractions) are small. Likewise the total organic carbon content is small (less than 0.3 wt\%), suggesting that Fe-cycling in the reservoir rock is carbon limited. Carbon limitation is also reflected in a low microbial abundance.

Leaching of $\mathrm{Fe}$ by acidification due to $\mathrm{CO}_{2}$-injection may also not significantly stimulate microbially driven $\mathrm{Fe}$ cycling. However, Fe-redox cycling may be stimulated by sedimentary organic matter mobilized by supercritical $\mathrm{CO}_{2}$. These results suggest that microbial activity can be induced by supply of organic substrate in combination with the $\mathrm{CO}_{2}$. Perhaps both the addition of hydrocarbons and freshening of the highly saline brine by the drilling fluid might stimulate Fe-cycling in the near-well area. For longterm interactions of the $\mathrm{CO}_{2}$ with the host rock (over thousands to millions of years), the alteration of clay minerals requires a more detailed examination, as this process may significantly buffer the acidification caused by the $\mathrm{CO}_{2}$.

Acknowledgements Open access funding provided by University of Vienna. XANES spectroscopy was performed at the lightsource DORIS III at DESY, a member of the Helmholtz Association (HFG). We would like to thank Edmund Welter for advice in using the A1 beamline at HASYLAB. We thank Andrea Schippers and Marie Dankworth for TOC and AVS/CRS analyses. We thank Maren Wandrey (GFZ Potsdam) for providing samples for this study and Stephanie Lerm, Tobias Lienen and Linda Pellizzari (GFZ Potsdam) and Timothy G. Ferdelman (MPI Bremen) for helpful comments. This study was supported by EU-Marie-Curie "GRASP" project MRTNCT-2006-035868, the H2STORE project, the $\mathrm{CO}_{2}$ SINK project and the Max Planck Institute for Marine Microbiology, Bremen. 
Open Access This article is distributed under the terms of the Creative Commons Attribution 4.0 International License (http://crea tivecommons.org/licenses/by/4.0/), which permits unrestricted use, distribution, and reproduction in any medium, provided you give appropriate credit to the original author(s) and the source, provide a link to the Creative Commons license, and indicate if changes were made.

\section{References}

Afonso MdS, Stumm W (1992) Reductive dissolution of iron(III) (hydr)oxides by hydrogen sulfide. Langmuir 8:1671-1675

Bickle M, Kampman N (2013) Lessons in carbon storage from geological analogues. Geology 41:525-526

Bock S, Förster H-J, Meier A, Förster A, Pudlo D, Gaupp R (2013) Impact of 4-year $\mathrm{CO}_{2}$ injection on reservoir-rock integrity at the $\mathrm{CO}_{2}$ pilot site Ketzin (Germany). Abstracts, AGU 2013 Fall Meeting (San Francisco 2013) (San Francisco, USA 2013)

Boetius A, Joye S (2009) Thriving in salt. Science 324:1523-1525

Boetius A, Ravenschlag K, Schubert CJ, Rickert D, Widdel F, Gieseke A, Amann R, Jørgensen BB, Witte U, Pfannkuche O (2000) A marine microbial consortium apparently mediating anaerobic oxidation of methane. Nature 407:623-626

Busigny V, Dauphas N (2007) Tracing paleofluid circulations using iron isotopes: a study of hematite and goethite concretions from the Navajo Sandstone (Utah, USA). Earth Planet Sci Lett 254:272-287

Canfield DE (1989) Reactive iron in marine sediments. Geochim Cosmochim Acta 53:619-632

Canfield DE, Raiswell R, Westrich JT, Reaves CM, Berner RA (1986) The use of chromium reduction in the analysis of reduced inorganic sulfur in sediments and shales. Chem Geol 54:149-155

Canfield DE, Raiswell R, Bottrell S (1992) The reactivity of sedimentary iron minerals toward sulfide. Am J Sci 292:659-683

Canfield DE, Thamdrup B, Hansen JW (1993) The anaerobic degradation of organic matter in Danish coastal sediments: iron reduction, manganese reduction, and sulfate reduction. Geochim Cosmochim Acta 57:3867-3883

Chan MA, Parry WT, Bowman JR (2000) Diagenetic hematite and manganese oxides and fault-related fluid flow in Jurassic sandstones, southeastern Utah. Am Assoc Pet Geol Bull 84:1281-1310

Chan MA, Beitler Bowen B, Parry WT, Ormö J, Komatsu G (2005) Red rock and red planet diagenesis: comparisons of Earth and Mars concretions. GSA Today 15:4-10

Chan MA, Ormö J, Park AJ, Stich M, Souza-Egipsy V, Komatsu G (2007) Models of iron oxide concretion formation: field, numerical, and laboratory comparisons. Geofluids 7:356-368

Cline JD (1969) Spectrophotometric determination of hydrogen sulfide in natural waters. Limnol Oceanogr 14:454-458

Coleman ML, Raiswell R (1995) Source of carbonate and origin of zonation in pyritiferous carbonate concretions. Am J Sci 295:282-308

Curtis CD, Coleman ML, Love LG (1986) Pore water evolution during sediment burial from isotopic and mineral chemistry of calcite, dolomite and siderite concretions. Geochim Cosmochim Acta 50:2321-2334

D’Hondt S, Jørgensen BB, Miller DJ, Batzke A, Blake R, Cragg BA, Cypionka H, Dickens GR, Ferdelman T, Hinrichs K-U, Holm NG, Mitterer R, Spivack A, Wang G, Bekins B, Engelen B, Ford K, Gettemy G, Rutherford SD, Sass H, Skilbeck CG, Aiello IW, Guèrin G, House C, Inagaki F, Meister P, Naehr T, Niitsuma S, Parkes RJ, Schippers A, Smith DC, Teske A, Wiegel J, Naranjo Padilla C, Solis Acosta JL (2004) Distributions of microbial activities in deep subseafloor sediment. Science 306:2216-2221
Enning D, Venzlaff H, Garrelfs J, Dinh HT, Meyer V, Mayrhofer K, Hassel AW, Stratmann M, Widdel F (2012) Marine sulfatereducing bacteria cause serious corrosion of iron under electroconductive biogenic mineral crust. Environ Microbiol 14:1772-1787

Fischer S, Liebscher A, Wandrey M, CO2-SINK Group (2010) $\mathrm{CO}_{2^{-}}$ brine-rock interaction-first results of long-term exposure experiments at in situ P-T conditions of the Ketzin $\mathrm{CO}_{2}$ reservoir. Chem Erde 70:155-164. doi:10.1016/j.chemer.2010. 06.001

Fischer S, Zemke K, Liebscher A, Wandrey M, The CO2SINK Group (2011) Petrophysical and petrochemical effects of long-term $\mathrm{CO}_{2^{-}}$ exposure experiments on brine-saturated reservoir sandstone. Energy Procedia 4:4487-4494. doi:10.1016/j.egypro.2011.02.404

Fischer S, Liebscher A, Zemke K, De Lucia M, Team Ketzin (2013) Does injected $\mathrm{CO}_{2}$ affect (chemical) reservoir system integrity? A comprehensive experimental approach. Energy Procedia 37:4473-4482. doi:10.1016/j.egypro.2013.06.352

Fisher QJ, Raiswell R, Marshall JD (1998) Siderite concretions from nonmarine shales (Westphalian A) of the Pennines, England: controls on their growth and composition. J Sediment Res 68:1034-1045

Förster A, Norden B, Zinck-Jørgensen K, Frykman P, Kulenkampff J, Spangenberg E, Erzinger J, Zimmer M, Kopp J, Borm G, Juhlin C, Cosma C-G, Hurter S (2006) Baseline characterization of the $\mathrm{CO}_{2}$ SINK geological storage site at Ketzin, Germany. Environ Geosci 13:145-161

Förster A, Schöner R, Förster H-J, Norden B, Blaschke A-W, Luckert J, Beutler G, Gaupp R, Rhede D (2010) Reservoir characterization of a $\mathrm{CO}_{2}$ storage aquifer: the upper Triassic Stuttgart formation in the Northeast German Basin. Mar Pet Geol 27:2156-2172

Fossing H, Jørgensen BB (1989) Measurement of bacterial sulfate reduction in sediments-evaluation of a single-step chromium reduction method. Biogeochemistry 8:205-222

Froelich P, Klinkhammer G, Bender M, Luedtke N, Heath G, Cullen D, Dauphin P, Hammond D, Hartman B, Maynard V (1979) Early oxidation of organic matter in pelagic sediments of the eastern equatorial Atlantic: suboxic diagenesis. Geochim Cosmochim Acta 43:1075-1090

Gournis D, Lappas A, Karakassides MA, Tobbens D, Moukarika A (2008) A neutron diffraction study of alkali cation migration in montmorillonites sample: Cs-mont-300. Phys Chem Miner $35: 49-58$

Grace RD (2007) Oil: an overview of the petroleum industry, 6th edn. Gulf Publishing Co., Houston

Grazulis S, Chateigner D, Downs RT, Yokochi AT, Quirós M, Lutterotti L, Manakova E, Butkus J, Moeck P, Le Bail A (2009) Crystallography open database-an open-access collection of crystal structures. J Appl Crystallogr 42:726-729

Hansel CM, Lentini CJ, Tang Y, Johnston DT, Wankel SD, Jardine PM (2015) Dominance of sulfur-fueled iron oxide reduction in low-sulfate freshwater sediments. ISME J 2015:1-13

Hillier S, Velde B (1992) Chlorite interstratified with a $7 \AA$ mineral: an example from offshore Norway and possible implications for the interpretation of the composition of diagenetic chlorites. Clay Miner 27:475-486

Holmkvist L, Ferdelman TG, Jørgensen BB (2011) A cryptic sulfur cycle driven by iron in the methane zone of marine sediment (Aarhus Bay, Denmark). Geochim Cosmochim Acta 75:35813599

Humphreys B, Smith SA, Strong GE (1989) Authigenic chlorite in Late Triassic sandstones from the Central Graben, North Sea. Clay Miner 24:427-444

IEA (International Energy Agency) (2013) World energy outlook special report 2013: redrawing the energy climate map. OECD/ IEA, Paris 
Im W-T, Liu Q-M, Lee Q-J, Kim S-Y, Lee S-T, Yi T-H (2010) Variovorax ginsengisoli sp. nov., a denitrifying bacterium isolated from soil of a ginseng field. Int J Syst Evol Microbiol 60:1565-1569. doi:10.1099/ijs.0.014514-0

IPCC (2005) Carbon dioxide capture and storage. In: Metz B, Davidson O, de Coninck H, Loos M, Meyer L (eds) IPCC spec reports. Cambridge University Press, UK, $431 \mathrm{pp}$

Ivandic M, Juhlin C, Lueth S, Bergmann P, Kashubin A, Sopher D, Ivanova A, Baumann G, Henninges J (2015) Geophysical monitoring at the Ketzin pilot site for $\mathrm{CO}_{2}$ storage: new insights into the plume evolution. Int J Greenh Gas Control 32:90-105

King GM (2006) Microbial carbon monoxide consumption in salt marsh sediments. FEMS Microbiol Ecol 59:2-9. doi:10.1111/j. 1574-6941.2006.00215.x

Kostka JE, Luther GW III (1994) Partitioning and speciation of solid phase iron in saltmarsh sediments. Geochim Cosmochim Acta 58:1701-1710

Kozur H, Bachmann GH (2010) The Middle Carnian wet intermezzo of the Stuttgart Formation (Schilfsandstein), Germanic Basin. Palaeogeogr Palaeoclimatol Palaeoecol 290:107-119

Kulp TR, Han S, Saltikov CW, Lanoil BD, Zargar K, Oremland RS (2007) Effects of imposed salinity gradients on dissimilatory arsenate reduction, sulfate reduction, and other microbial processes in sediments from two California soda lakes. Appl Environ Microbiol 73:51305137

Lackner KS (2003) A guide to $\mathrm{CO}_{2}$ sequestration. Science 300:1677-1678

Lee K, Kostka JE, Stucki JW (2006) Comparisons of structural iron reduction in smectites by bacteria and dithionite: an infrared spectroscopic study. Clay Clay Miner 54:195-208

Lichtschlag A, James RH, Stahl H, Connelly D (2015) Effect of a controlled sub-sea bed release of $\mathrm{CO}_{2}$ on the biogeochemistry of shallow marine sediments, their pore waters, and the overlying water column. Int J Greenh Gas Control 38:80-92

Lipson DA, Jha M, Raab TK, Oechel WC (2010) Reduction of iron(III) and humic substances plays a major role in anaerobic respiration in an Arctic peat soil. J Geophys Res 115:1-13

Lovley DR, Phillips EJP (1986) Availability of ferric iron for microbial reduction in bottom sediments of the freshwater tidal Potomac River. Appl Environ Microbiol 52:751-757

Lovley DR, Phillips EJP (1987) Competitive mechanisms for inhibition of sulfate reduction and methane production in the zone of ferric iron reduction in sediments. Appl Environ Microbiol 53:2636-2641

Martens S, Kempka T, Liebscher A, Lüth S, Möller F, Myrttinen A, Norden B, Schmidt-Hattenberger C, Zimmer M, Kühn M, the Ketzin Group (2012) Europe's longest-operating on-shore $\mathrm{CO}_{2}$ storage site at Ketzin, Germany: a progress report after three years of injection. Environ Earth Sci 67:323-334

Martens S, Liebscher A, Möller F, Henninges J, Kempka T, Lüth S, Norden B, Prevedel B, Szizybalski A, Zimmer M, Kühn M, the Ketzin Group (2013) $\mathrm{CO}_{2}$ storage at the Ketzin pilot site, Germany: fourth year of injection, monitoring, modelling and verification. Energy Procedia 37:6434-6443

Martens S, Möller F, Streibel M, Liebscher A (2014) Completion of five years of safe $\mathrm{CO}_{2}$ injection and transition to the post-closure phase at the Ketzin pilot site. Energy Procedia 59:190-197

Meister P (2015) For the deep biosphere, the present is not always the key to the past: what we can learn from the geological record. Terra Nova 27:400-408

Meister P, Bernasconi S, McKenzie JA, Vasconcelos C, Frank M, Gutjahr M, Schrag D (2007) Dolomite formation in the dynamic deep biosphere: results from the Peru Margin (ODP Leg 201). Sedimentology 54:1007-1032

Meister P, Gutjahr M, Frank M, Bernasconi S, Vasconcelos C, McKenzie JA (2011) Dolomite formation within the methanogenic zone induced by tectonically-driven fluids in the Peru accretionary prism. Geology 39:563-566

Meister P, Chapligin B, Picard A, Meyer H, Fischer C, Rettenwander D, Amthauer G, Vogt C, Aiello IW (2014) Early diagenetic quartz formation at a deep iron oxidation front in the Eastern Equatorial Pacific. Geochim Cosmochim Acta 137:188-207

Meunier A (2005) Clays. Springer, Berlin, p 472

Meunier A, Velde B (2004) Illite-origins, evolution and metamorphism. Springer, Berlin, p 289

Moore DM, Reynolds RC (1997) X-ray diffraction and the identification and analysis of clay minerals, 2nd edn. Oxford University Press, Oxford

Morozova D, Zettlitzer M, Let D, Würdemann H, CO2SINK Group (2011) Monitoring of the microbial community composition in deep subsurface saline aquifers during $\mathrm{CO}_{2}$ storage in Ketzin, Germany. Energy Procedia 4:4362-4370

Nauhaus K, Albrecht M, Elvert M, Boetius A, Widdel F (2007) In vitro cell growth of marine archaeal-bacterial consortia during anaerobic oxidation of methane with sulfate. Environ Microbiol 9(1):187-196. doi:10.1111/j.1462-2920.2006.01127.x

Newville M (2001) IFFEFIT: interactive XAFS analysis and FEFF fitting. J Synchrotron Radiat 8:322-324

Norden B, Frykman F (2013) Geological modelling of the Triassic Stuttgart formation at the Ketzin $\mathrm{CO}_{2}$ storage site, Germany. Int J Greenh Gas Control 19:756-774

Norden B, Förster A, Vu-Hoang D, Marcelis F, Springer N, Le Nir I (2010) Lithological and petrophysical core-log interpretation in the $\mathrm{CO}_{2}$-SINK, the European $\mathrm{CO}_{2}$ onshore research storage and verification project. SPE Reserv Eval Eng 13:179-192

Park JM, Kim TY, Lee SY (2011) Genome-scale reconstruction and in silico analysis of the Ralstonia eutropha H16 for polyhydroxyalkanoate synthesis, lithoautotrophic growth, and 2-methyl citric acid production. BMC Syst Biol 5:101. doi:10.1186/17520509-5-101

Parkes RJ, Webster G, Cragg B, Barry A, Weightman AJ, Newberry CJ, Ferdelman TG, Kallmeyer J, Jørgensen BB, Aiello IW, Fry JC (2005) Deep sub-seafloor prokaryotes stimulated at interfaces over geological time. Nature 436:390-394

Parry WT, Forster CB, Evans JP, Beitler Bowen B, Chan MA (2007) Geochemistry of $\mathrm{CO}_{2}$ sequestration in the Jurassic Navajo Sandstone, Colorado Plateau, Utah. Environ Geosci 14:91-109

Pellizzari L, Neumann D, Alawi M, Voigt D, Norden B, Würdemann $H$ (2013) The use of tracers to assess drill-mud penetration depth into sandstone cores during deep drilling: method development and application. Environ Earth Sci 70(8):3727-3738

Pellizzari L, Morozova D, Neumann D, Klapperer S, Kasina M, Zettlitzer M, Würdemann H (2016) Comparison of the microbial community composition of the well and saline aquifer fluids and of rock cores at the Ketzin $\mathrm{CO}_{2}$ storage site-results of geochemical and molecular biological characterisation. Environ Earth Sci 75:1323. doi:10.1007/s12665-016-6111-6

Pellizzari L, Kasina M, Würdemann H (2017) Influence of drill mud on the microbial communities of sandstone rocks and well fluids at the Ketzin pilot site for $\mathrm{CO}_{2}$ storage. Environ Earth Sci. doi:10.1007/s12665-016-6381-z

Pirngruber GD, Luechinger M, Roy PK, Cecchetto A, Smirniotis P (2004) $\mathrm{N}_{2} \mathrm{O}$ decomposition over iron-containing zeolites prepared by different methods: a comparison of the reaction mechanism. J Catal 224:429-440

Poulton SW, Canfield DE (2005) Development of a sequential extraction procedure for iron: implications for iron partitioning in continentally-derived particulates. Chem Geol 214:209-221

Prevedel B, Wohlgemuth L, Henninges J, Krüger K, Norden B, Förster A, CO2SINK Drilling Group (2008) The CO2SINK boreholes for geological storage testing. Sci Drill 6:32-37. doi:10.2204/iodp.sd.6.04.2008 
Raiswell R, Canfield DE, Berner RA (1994) A comparison of iron extraction methods for the determination of degree of pyritisation and the recognition of iron-limited pyrite formation. Chem Geol 111:101-110

Ravel B, Newville M (2005) ATHENA, ARTEMIS, HEPHAESTUS: data analysis for X-ray absorption spectroscopy using IFEFFIT. J Synchrotron Radiat 12:537-541

Reyes C, Dellwig O, Dähnke K, Gehre M, Noriega-Ortega BE, Böttcher ME, Meister P, Friedrich MW (2016) Bacterial communities potentially involved in iron-cycling in Baltic Sea and North Sea sediments revealed by pyrosequencing. FEMS Microbiol Ecol 92:1-14

Ribeiro FR, Fabris JD, Kostka JE, Komadel P, Stucki JW (2009) Comparisons of structural iron reduction in smectites by bacteria and dithionite: II. A variable-temperature Mössbauer spectroscopic study of Garfield nontronite. Pure Appl Chem 81:1499-1509

Riedinger N, Formolo MJ, Lyons TW, Henkel S, Beck A, Kasten S (2014) An inorganic geochemical argument for coupled anaerobic oxidation of methane and iron reduction in marine sediments. Geobiology 12:172-181

Robert C, Kennett JP (1994) Antarctic subtropical humid episode at the Palaeo-Eocene boundary: clay-mineral evidence. Geology 22:211-214

Rodriguez NM, Paull CK, Borowski WS (2000) Zonation of authigenic carbonates within gas hydrate-bearing sedimentary sections on the Blake Ridge: offshore southeastern North America. In: Paull CK, Matsumoto R, Wallace PJ, Dillon, WP (eds) Proceedings of the ODP science results, vol 164, pp 301-312

Santelli CM, Welch SA, Westrich HR, Banfield JF (2001) The effect of Fe-oxidizing bacteria on Fe-silicate mineral dissolution. Chem Geol 180:99-115

Scherf A-K, Zetzl C, Smirnova I, Zettlitzer M, Vieth-Hillebrand A, CO2SINK Group (2011) Mobilisation of organic compounds from reservoir rocks through the injection of $\mathrm{CO}_{2}$ - comparison of baseline characterization and laboratory experiments. Energy Procedia 4:4524-4531

Schilling F, Borm G, Würdemann H, Möller F, Kühn M, CO2SINK Group (2009) Status report on the first European on-shore $\mathrm{CO}_{2}$ storage site at Ketzin (Germany). Energy Procedia 1:2029-2035

Scholz F, Hensen C, Schmidt M, Geersen J (2013) Submarine weathering of silicate minerals and the extent of pore water freshening at active continental margins. Geochim Cosmochim Acta 100:200-216

Schwertmann U, Cornell RM (2000) Iron oxides in the laboratorypreparation and characterization, 2nd edn. Wiley-VCH, Weinheim, p 188

Seabaugh JL, Dong H, Kukkadapu RK, Eberl DD, Morton JP, Kim J (2006) Microbial reduction of $\mathrm{Fe}(\mathrm{III})$ in the Fithian and Muloorina illites: contrasting extents and rates of bioreduction. Clays Clay Miner 54:67-79

Shilobreeva S, Martinez I, Busigny V, Agrinier P, Laverne C (2011) Insights into $\mathrm{C}$ and $\mathrm{H}$ storage in the altered oceanic crust: results from ODP/IODP Hole 1256D. Geochim Cosmochim Acta 75:2237-2255

Shishkina TA, Botcharnikov RE, Holtz F, Almeev RR, Portnyagin MV (2010) Solubility of $\mathrm{H}_{2} \mathrm{O}$ - and $\mathrm{CO}_{2}$-bearing fluids in tholeiitic basalts at pressures up to $500 \mathrm{MPa}$. Chem Geol 277:115-125. doi:10.1016/j.chemgeo.2010.07.014

Stucki JW, Kostka JE (2006) Microbial reduction of iron in smectite. C R Geosci 338:468-475

Tiemeyer A, Link H, Weuster-Botz D (2007) Kinetic studies on autohydrogenotrophic growth of Ralstonia eutropha with nitrate as terminal electron acceptor. Appl Microbiol Biotechnol $76: 75-81$
Wächtershäuser G (1988) Pyrite formation, the first energy source for life: a hypothesis. Syst Appl Microbiol 10:207-210

Wallmann K, Aloisi G, Haeckel M, Tishchenko P, Pavlova G, Greinert J, Kutterolf S, Eisenhauer A (2008) Geochim Cosmochim Acta 72:3067-3090

Wandrey M, Morozova D, Zettlitzer $M$, Würdemann $H$, the CO2SINK Group (2010) Assessing drilling mud and technical fluid contamination in rock core and brine samples intended for microbiological monitoring at the $\mathrm{CO}_{2}$ storage site in Ketzin using fluorescent dye tracers. Int $\mathrm{J}$ Greenh Gas Control 4(6):972-980. doi:10.1016/j.ijggc.2010.05.012

Wandrey M, Pellizari L, Zettlitzer M, Würdemann H (2011a) Microbial community and inorganic fluid analysis during $\mathrm{CO}_{2}$ storage within the frame of $\mathrm{CO}_{2} \mathrm{SINK}$-long-term experiments under in situ conditions. Energy Procedia 4:3651-3657

Wandrey M, Fischer S, Zemke K, Liebscher A, Scherf A-K, ViethHillebrand A, Zettlitzer M, Würdemann H (2011b) Monitoring petrophysical, mineralogical, geochemical and microbiological effects of $\mathrm{CO}_{2}$ exposure-results of long-term experiments under in situ conditions. Energy Procedia 4:3644-3650

Wankel SD, Adams MM, Johnston DT, Hansel CM, Joye SB, Girguis PR (2012) Anaerobic methane oxidation in metalliferous hydrothermal sediments: influence on carbon flux and decoupling from sulfate reduction. Environ Microbiol 14:2726-2740

Wehrmann LM, Knab NJ, Pirlet H, Unnithan V, Wild C, Ferdelman TG (2009) Carbon mineralization an carbonate preservation in modern cold-water coral reef sediments on the Norwegian shelf. Biogeosciences 6:663-680

Wehrmann LM, Ockert C, Mix A, Gussone N, Teichert BMA, Meister P (2016) Multiple onset of methanogenic zones, diagenetic dolomite formation, and silicate alteration under varying organic carbon deposition in Bering Sea sediments (Bowers Ridge, IODP Exp. 323 Site U1341). Deep Sea Res II 125-126:117-132

Wien K, Wissmann D, Kölling M, Schulz HD (2005) Fast application of X-ray fluorescence spectrometry aboard ship: how good is the new portable Spectro Xepos analyser? Geo-Mar Lett 25:248-264

Wiese B, Nimtz M, Klatt M, Kühn M (2010) Sensitivities of injection rates for single well $\mathrm{CO}_{2}$ injection into saline aquifers. Chem Erde 70:165-172

Wilke M, Farges F, Petit P-E, Brown GE Jr, Martin F (2001) Oxidation state and coordination of $\mathrm{Fe}$ in minerals: an $\mathrm{Fe}$ K-XANES spectroscopic study. Am Mineral 86:714-730

Wilkin RT, Barnes HL (1996) Pyrite formation by reactions of iron monosulfides with dissolved inorganic and organic sulfur species. Geochim Cosmochim Acta 60:4167-4179

Wojdyr M (2010) Fityk: a general-purpose peak fitting program. J Appl Cryst 43:1126-1128

Würdemann H, Möller F, Kühn M, Heidug W, Christensen NP, Borm G, Schilling FR, the CO2SINK Group (2010) CO2SINK - From site characterisation and risk assessment to monitoring and verification: one year of operational experience with the field laboratory for $\mathrm{CO}_{2}$ storage at Ketzin, Germany. Int J Greenh Gas Control 4:938-995

Zettlitzer M, Möller F, Morozova D, Lokay P, Würdemann H, the CO2SINK Group (2010) Re-establishment of the proper injectivity of the $\mathrm{CO}_{2}$-injection well Ktzi 201 in Ketzin, Germany. Int $\mathbf{J}$ Greenh Gas Control 4:952-959. doi:10.1016/j.ijggc.2010.05.006

Zimmer M, Erzinger J, Kujawa C, the CO2-SINK Group (2011) The gas membrane sensor (GMS): a new method for gas measurements in deep boreholes applied at the $\mathrm{CO}_{2} \mathrm{SINK}$ site. Int $\mathrm{J}$ Greenh Gas Control 5:995-1001

Zweigel P, Arts R, Lothe AE, Lindeberg EBG (2004) Reservoir geology of the Utsira Formation at the first industrial-scale underground $\mathrm{CO}_{2}$ storage site (Sleipner area, North Sea). Geol Soc Lond Spe Publ 233:165-180 